\title{
GEOLOGIA, PETROGRAFIA E LITOGEOQUÍMICA DO COMPLEXO GRANÍTICO TRÊS CÓRREGOS NA REGIÃO DE BARRA DO CHAPÉU E RIBEIRÃO BRANCO, SP
}

\author{
ANTONIO GIMENEZ FILHO*, WILSON TEIXEIRA**, MARIO C. H. FIGUEIREDO" E \\ LUIZ E. TREVIZOLI JÚNIOR****
}

\begin{abstract}
GEOLOGY, PETROGRAPHY AND GEOCHEMISTRY OF THE TRÊS CÓRREGOS GRANITIC COMPLEX IN THE BARRA DO CHAPEUU AND RIBEIRÃO BRANCO AREA, SP. In this work we consider that the Três Córregos Granitic complex is mainly made up of porphyroid to foliated granitoids. A post-tectonic granite suite and a body of augen gneisses, interpreted as a mega-enclave, also occur. The augen gneisses, with quartz dioritic to quartz monzomtic enclaves, have chemical compositions which differ from those of the more abundant Três Córregos granitoids and appear to characterize a high-Al calc-alkaline sequence. The Três Córregos granitoids are mostly porphyritic, hornblende and biotite-bearing, but leucocratic microporphyntic to equigranular granites also occur, as well as foliated granitoids with similar compositions to the other granitoids. Mafic enclaves, mostly potassic diorites, are common. The granitoids and mafic enclaves appear to define an expanded sequence with high-K calc-alkaline characteristics and incompatible element distribution, including the Rare Earth elements, with typical subduction zone components. The K-dioritic enclaves may correspond to magmas derived by partial melting of a supra-subduction zone enriched mantle, at least with some crustal contamination during its evolution, storage and emplacement. The intermediate-acid granitoids appear to be related to the mafic enclaves, but the precise mechanism of this relationship is still elusive. The post-tectonic granites are highly differentiated and probably correspond to intra-plate crustal melts.
\end{abstract}

Keywords: Granitoids, Neoproterozoic, enclaves, high-K calc-alkaline.

RESUMO Neste trabalho, considera-se que o Complexo Granítico Três Córregos é constituído predominantemente por granitóides porfiróides a orientados. Além disso, ocorrem na região uma suíte de granitos póstectônicos e um corpo de augen gnaisses, interpretado como megaenclave. Os augen gnaisses, contendo enclaves quartzo dioríticos a quartzo-monzoníticos, têm composições distintas daquelas dos granitóides mais abundantes, e parecem, apesar do número muito reduzido de amostras analisadas, caracterizar uma seqüência cálcioalcalina de alto-Al. Os granitóides Três Córregos são constituídos predominantemente por hornblenda-biotita granitóides porfiróides e granitos leucocráticos microporfiríticos a equigranulares, além de granitóides orientados, que apresentam composições semelhantes às dos outros granitóides. Comumente encontram-se enclaves máficos de composição predominantemente diorítica potássica. Os granitóides e enclaves máficos parecem constituir uma seqüência expandida cálcio-alcalina de alto-K, com distribuição de elementos incompatíveis, incluindo os elementos Terras Raras, com típicos componentes de zona de subducção. Os enclaves dioríticos potássicos podem corresponder a magmas derivados por fusão parcial de manto enriquecido, em cunha do manto acima de uma zona de subducção, com pelo menos alguma contaminação crustal durante sua evolução, armazenagem e colocação. Os granitóides intermediárío-ácidos parecem estar relacionados aos K-diorítos mas o mecanismo preciso deste relacionamento é ainda impreciso. Os granitos pós-tectônicos são fortemente diferenciados e correspondem provavelmente a fusões crustais em ambiente intraplaca.

Palavras-chave: Granitóides, Neoproterozóico, enclaves, cálcio-alcalino de alto-K.

INTRODUÇÃO A área do Complexo Granítico Três Córregos foi objeto, na década de 1980, de modelagens de evolução tectônica que consideravam as porções de rochas granitóides deformadas e/ou orientadas como pertencentes a um embasamento de idade arqueana. Por outro lado, diversos autores defendiam a linha de interpretação que mantinha tais rochas no complexo Três Córregos e considerava-as como formadas no Neoproterozóico.

Os resultados obtidos no presente trabalho vêm se alinhar com o modelo neoproterozóico, com os granitóides sendo formados em um ambiente de arco magmático, provavelmente de margem continental ativa.

A área estudada abrange aproximadamente $900 \mathrm{~km}^{2}$ e localiza-se na porção sudoeste dó Estado de São Paulo, junto ao limite com o Estado do Paraná, a sul da cidade de Itapeva (SP) e a norte de Curitiba (PR). Á figura 1 apresenta um esboço geológico de toda a área do Complexo Três Córregos, bem como das demais unidades geológicas do embasamento cristalino da região situada entre a Bacia do Paraná, a noroeste, e o Lineamento de Lancinha-Itapeúna, a sudeste.
Métodos Utilizados nas Análises Químicas As análises químicas foram efetuadas no GEOLAB, divisão de laboratórios da GEOSOL, em outubro de 1991.

Os óxidos $\mathrm{SiO}_{2}, \mathrm{~A}_{2} \mathrm{O}_{3}, \mathrm{Fe}_{2} \mathrm{O}_{3}, \mathrm{MgO}, \mathrm{CaO}, \mathrm{TiO}_{2}$ e $\mathrm{P}_{2} \mathrm{O}_{5}$ foram determinados por fluorescência de raios $\mathrm{X}$ (aparelho Rigaku Denki "Geigerflex"), cujos limites de detecção são de $0,10 \%$, exceto para os três últimos óxidos, onde o limite é de $0,05 \%$. Para análise, o pó das amostras foi fundido com tetraborato de lítio com adição de oxido de lantânio.

$\mathrm{Na}$ determinação de $\mathrm{FeO}$ (limite de detecção de 0,05\%) por volumetria, procedeu-se a titulação de $\mathrm{Fe}^{2+}$ por solução padrão de $\mathrm{K}_{2} \mathrm{Cr}_{2} \mathrm{O}_{7}$ em presença de defenissulfato de sódio como indicador.

Foram determinados por absorção atômica, após abertura com $\mathrm{HF}$ e $\mathrm{HC}_{10}$, os óxidos $\mathrm{Na}_{2} \mathrm{O}, \mathrm{K}_{2} \mathrm{O}$ e $\mathrm{MnO}$, com limite de detecção de $0,01 \%$.

Os elementos traços foram analisados por fluorescência de raios X (técnica de pó prensado), em espectrômetro com potencial de $100 \mathrm{Kv}$, com opção de se trabalhar com tubo de ródio, cromo ou tungstênio, cujos limites de detecção são: $\mathrm{Ba}=15$ ppm; $\mathrm{V}=10$ ppm; $\mathrm{Nb}=8$ ppm; Rb, Sr, Zr e Y $=5$

\footnotetext{
* Divisão de Geologia, Instituto de Pesquisas Tecnológicas do Estado de São Paulo, Caixa Postal 7141, CEP 01064-970, São Paulo, SP, Brasil. ** Instituto de Geociências, Universidade de São Paulo, Caixa Postal 11.348, CEP 05422-970, São Paulo, SP, Brasil.

*** Rua Bento da Cruz, 553, Centro, CEP 16200-000 Birigüi, SP, Brasil.
} 


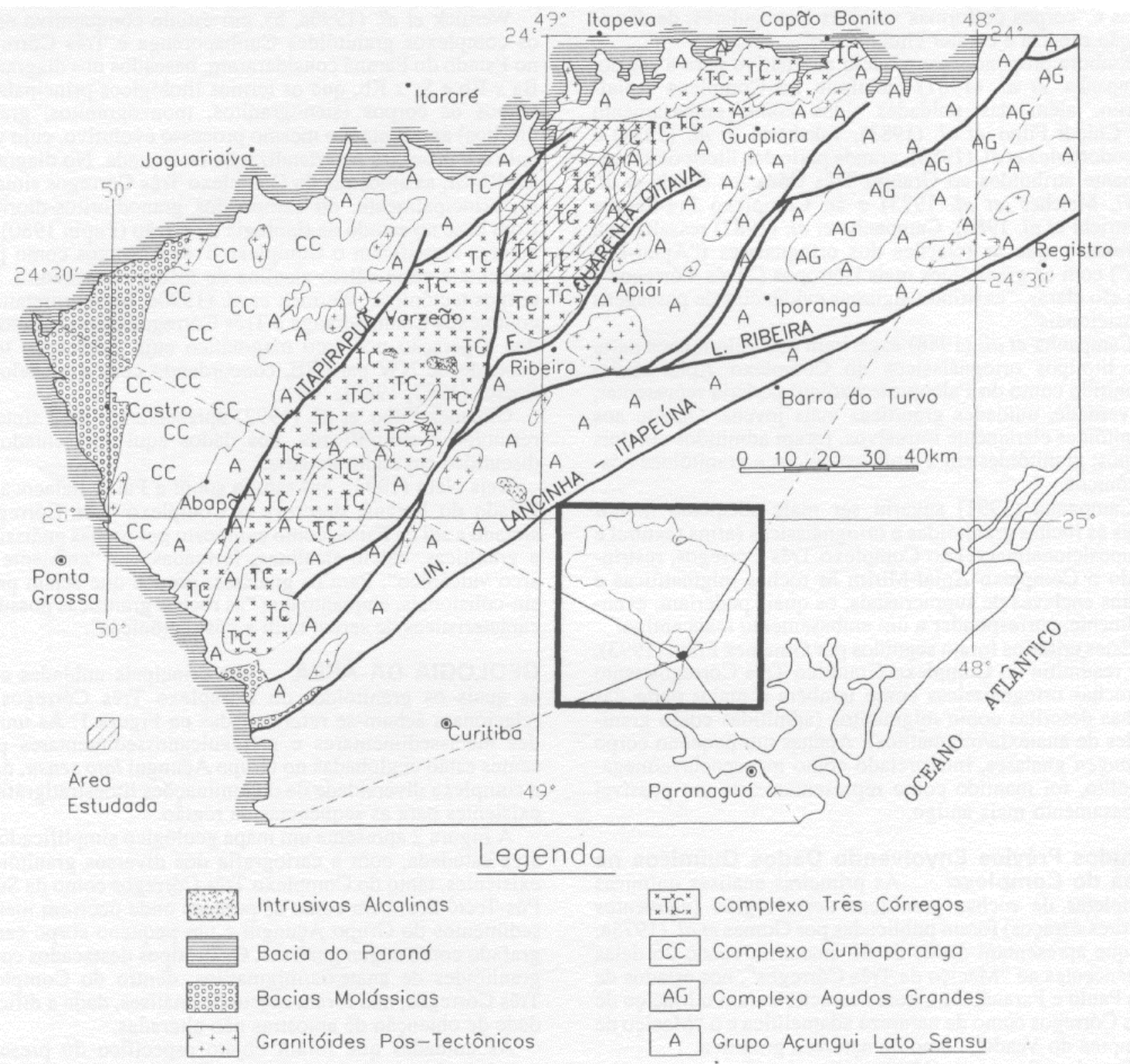

Figural - Localização da área e esboço geológico regional Figure 1 - Area location and geological sketch map

ppm. Na determinação dos elementos terras raras as técnicas utilizadas constam de separação em coluna de troca iônica com dosagem por espectrometria de plasma ICP (Dutra 1984). Os limites de detecção são: $\mathrm{La}$ e $\mathrm{Nd}=0,5 \mathrm{ppm}$; $\mathrm{Ce}=1,0$ ppm; Sm e Dy =0,1 ppm; Eu, Ho, Er e Yb=0,05 ppm; $\mathrm{Gd}=0,2 \mathrm{ppm}$; e $\mathrm{Lu}=0,03 \mathrm{ppm}$. O aparecimento de ocasional enriquecimento anômalo de Lu parece ser devido a erro analítico.

Foram analisados por gravimetria $\mathrm{H}_{2} \mathrm{O}^{-}$(método de perda de peso a $110^{\circ} \mathrm{C}$ ) e $\mathrm{H}_{2} \mathrm{O}^{+}$(método Penfield), ambos com limite de detecção de $0,01 \%$, enquanto que na determinação de $\mathrm{F}$ utilizou-se a técnica do eletrodo de íon específico (fusão alcalina), com limite de detecção de $0,03 \%$.

HISTÓRICO A denominação de Granito Três Córregos foi utilizada primeiramente por Fuck (1966) para as rochas graníticas existentes na porção nordeste da quadrícula Quero-Quero (PR). Estas rochas se estendem para leste, adentrando a quadrícula Campo Largo (PR), para as quais Muratori (1966) adotou a mesma denominação.
Para Fuck et al. (1967), o batólito Três Córregos estende-se desde a região de Itaiacoca-Três Córregos (PR) até o rio Itapirapuã, adentrando então o Estado de São Paulo, onde constitui parte da Serra de Paranapiacaba. Melcher et al. (1973) estudaram a porção aflorante do Granito Três Córregos no Estado de São Paulo, na qual o mesmo é classificado corno do tipo porfiróide e de caráter sin a tarditectônico.

Dada a grande variedade litológica, textural e composicional observada nesta imensa massa batolítica, Paiva et al. (1977) passaram a denominá-lo de Complexo Granítico Três Córregos.

Hasui et al. (1984) consideraram a área do Complexo Três Córregos como um alto do embasamento ("Maciço Catas Altas") e as rochas graníticas deformadas foram interpretadas como ortognaisses oriundos de uma evolução por megazonas de cisalhamento dúctil sub-horizontais, relacionadas a cinturões móveis de idade "arqueana tardia". Tais ortognaisses foram admitidos (Hasui et al. 1984) no Complexo Setuva e os granitos propriamente ditos ficaram rés- 
tritos a "corpos de formas variadas e irregulares, de distribuição esparsa e caráter circunscrito".

Embora propondo um modelo alternativo para a região, Campanha et al. (1987) incluíram no Complexo ApiaíMirím, além das unidades tidas como embasamento por Chiodi Filho et al (1983), Takahashi et al. (1984) e Theodorovicz et al. (1988), grande parte dos litotipos anteriormente atribuídos ao Granito Três Córregos (Fuck et al. 1967, Melcher et al 1973) e ao Complexo Pré-Setuva (Bistrichi et al 1985). Campanha et al (1987) ressaltaram, entretanto, que as relações dos ortognaisses ("Apiaí-Mirim") com os granitóides mais isótropos ('Três Córregos") não são claras, "existindo algumas evidências de passagens transicionais".

Campanha et al (1988) sugeriram que pelo menos parte dos litotipos ortognáissicos do Complexo Apiaí-Mirim (admitido como do Paleoproterozóico) poderia representar, na verdade, unidades graníticas mais jovens. Quanto aos granitóides claramente intrusivos, foram admitidos em dois grupos: granitóides sin a tardi-tectônicos e granitóides póstectônicos.

Campanha (1991) sugeriu ser mais adequado incluir todas as rochas granitóides e ortognáissicas (afins textural e composicionalmente) no Complexo Três Córregos, restringindo o Complexo Apiaí-Mirim às rochas migmatíticas e alguns enclaves de supracrustais, os quais poderiam, eventualmente, corresponder a um embasamento mais antigo.

Estes critérios foram seguidos por Gimenez Filho (1993), que readmitiu no Complexo Granítico Três Córregos tanto as rochas ortognáissicas como também a maior parte das rochas descritas como migmatitos (admitidas como granitóides de anatexia/migmatitos). Apenas um pequeno corpo de augen gnaisses, interpretado como megaenclave/megaxenólito, foi mantido como representante de um possível embasamento mais antigo.

Estudos Prévios Envolvendo Dados Químicos na Área do Complexo As primeiras análises químicas completas de rochas graníticas desta região (elementos maiores e traços) foram publicadas por Gomes et al (1975a, b), que apresentam dados de 81 amostras, sendo 26 delas pertencentes ao "Maciço de Três Córregos", nos estados de São Paulo e Paraná. Os autores caracterizaram o Maciço de Três Córregos como de natureza adamelítica e o "Maciço de Campina do Veado" como de natureza granítica.

Theodorovicz et al (1988) caracterizaram os ortognaisses do Complexo Metamórfico Apiaí-Mirim (granitóides orientados, neste trabalho) e os granitos Capote e Paiol de Telha (Suíte Porfiróide) como do tipo I, pouco diferenciados. Os granitos Sguário e Campina do Veado (Suíte Granítica Pós-Tectônica) também foram considerados como do tipo-I, no entanto, bastante diferenciados.

Goraieb et al $(1987,1988)$ enfatizaram as mineralizações do Granito Correias (com análise química de uma amostra) onde este é definido "como unidade intrusiva póstectônica de caráter anorogênico distensivo em ambiente cratogênico, apresentando características de especialização metalogenética". Tais autores correlacionaram o Granito Correias à Suíte Intrusiva Serra do Mar (e.g., Kaul 1984), e sugeriram uma relação genética desse granito com o Granito Sguário.

Chiodi Filho et al (1989), em estudo de elementos terras raras para caracterização e avaliação metalogenética de granitoides no Escudo Paranaense (envolvendo porções do PR e SP), colocam o Complexo Três Córregos no grupo dos granitos pré-colisionais, com filiação granodiorítica e de origem mantélica. Estes autores correlacionam os granitos Sguário e Campina do Veado aos granitos Morro Grande e Banhado, por eles tidos como sin-colisionais, de filiação monzogábrica/sienogranítica e de origem crustal.
Wernick et al (1990a, b), em estudo comparativo entre os complexos granitóides Cunhaporanga e Três Córregos no Estado do Paraná consideraram, baseados nos diagramas Ba $x \mathrm{Rb}$ e Sr $x \mathrm{Rb}$, que os termos litológicos principais de ambos os corpos (sienogranitos, monzogranitos, granodioritos) apresentam o mesmo processo evolutivo, cujo vínculo é o processo de cristalização fracionada. No diagrama $\mathrm{Ba}-\mathrm{Rb}$-Sr, as amostras do Complexo Três Córregos situamse, principalmente, no campo dos granodioritos-dioritos. Com base no estudo da tipologia de zircão (Pupin 1980), os autores classificam o Complexo Três Córregos como pertencente à série cálcio-alcalina de média temperatura. Em termos tectônicos, Wernick et al (1990a, b) interpretam os complexos Cunhaporanga e Três Córregos como relacionados à geração por arco magmático cuja subducção teria ocorrido de NW para SE, concordando com o modelo de Soares $(1987,1988)$.

Gimenez Filho et al (1992) apresentaram uma síntese, resumida e simplificada, dos dados aqui apresentados e discutidos em maior detalhe.

Reis Neto (1994), em estudo sobre a Faixa Itaiacoca no Estado do Paraná, descreve o Complexo Três Córregos, situado a sul da Faixa, como composto por rochas gnáissicas e graníticas, cálcio-alcalinas, formadas em "ambiente de arco vulcânico". Para os gnaisses, propõe que sejam pré a sin-colisionais, enquanto que "as rochas graníticas possuem características de serem tardi a pós-tectônicas".

GEOLOGIA DA ÁREA As principais unidades com as quais os granitóides do Complexo Três Córregos se relacionam acham-se referenciadas na Figura 1. As unidades metassedimentares e metavulcanossedimentares presentes estão englobadas no Grupo Açungui lato sensu, dada a complexa diversidade de denominações litoestratigráficas existentes para as seqüências da região.

A Figura 2 apresenta um mapa geológico simplificado da área estudada, com a cartografia dos diversos granitóides existentes, tanto do Complexo Três Córregos como da Suíte Pós-Tectônica, bem como as porções onde ocorrem metassedimentos do Grupo Açungui e um pequeno corpo cartografado como augen gnaisses. Os litotipos destacados como granitóides de anatexia/migmatitos, dentro do Complexo Três Córregos, não foram objeto de análises, dada a dificuldade de obtenção de amostras não alteradas.

As unidades que foram objeto específico do presente trabalho são: os augen gnaisses, o Complexo Granítico Três Córregos (Granitóides Orientados, Suíte Porfiróide e Granito Lajeado) e a Suíte Granítica Pós-Tectônica.

Augen Gnaisses Esta unidade compreende apenas um corpo (2, na Fig. 2), no qual predominam augen gnaisses contendo enclaves de gnaisses finos de coloraçâo mais escura e, por vezes, veios graníticos róseos.

Complexo Granítico Três Córregos Este Complexo é a unidade de maior expressão na ảrea estudada, tendo sido nele reconhecidos quatro conjuntos litológicos (Gimenez Filho 1993): a. Granitóides de anatexia/migmatitos (não estudados no presente trabalho); b. Granitóides orientados; c. Suíte Porfiróide; e d. Granito Lajeado. Em diversos afloramentos, tanto dos granitóides orientados quanto de granitos da Suíte Porfiróide, foram constatados enclaves de rocha de granulação mais fina, em geral orientados e de coloração escura, os quais foram também objeto do estudo.

Granitóides Orientados Sob esta designação englobamse as rochas referidas como ortognaisses e incluídas anteriormente no Complexo Pré-Setuva (Bistrichi et al 1985) e aquelas enfeixadas como granitos gnáissicos porfiroblásticos e ortognaisses, que foram incluídas no Complexo Metamórfico Apiaí-Mirim por Theodorovicz et al (1988). 


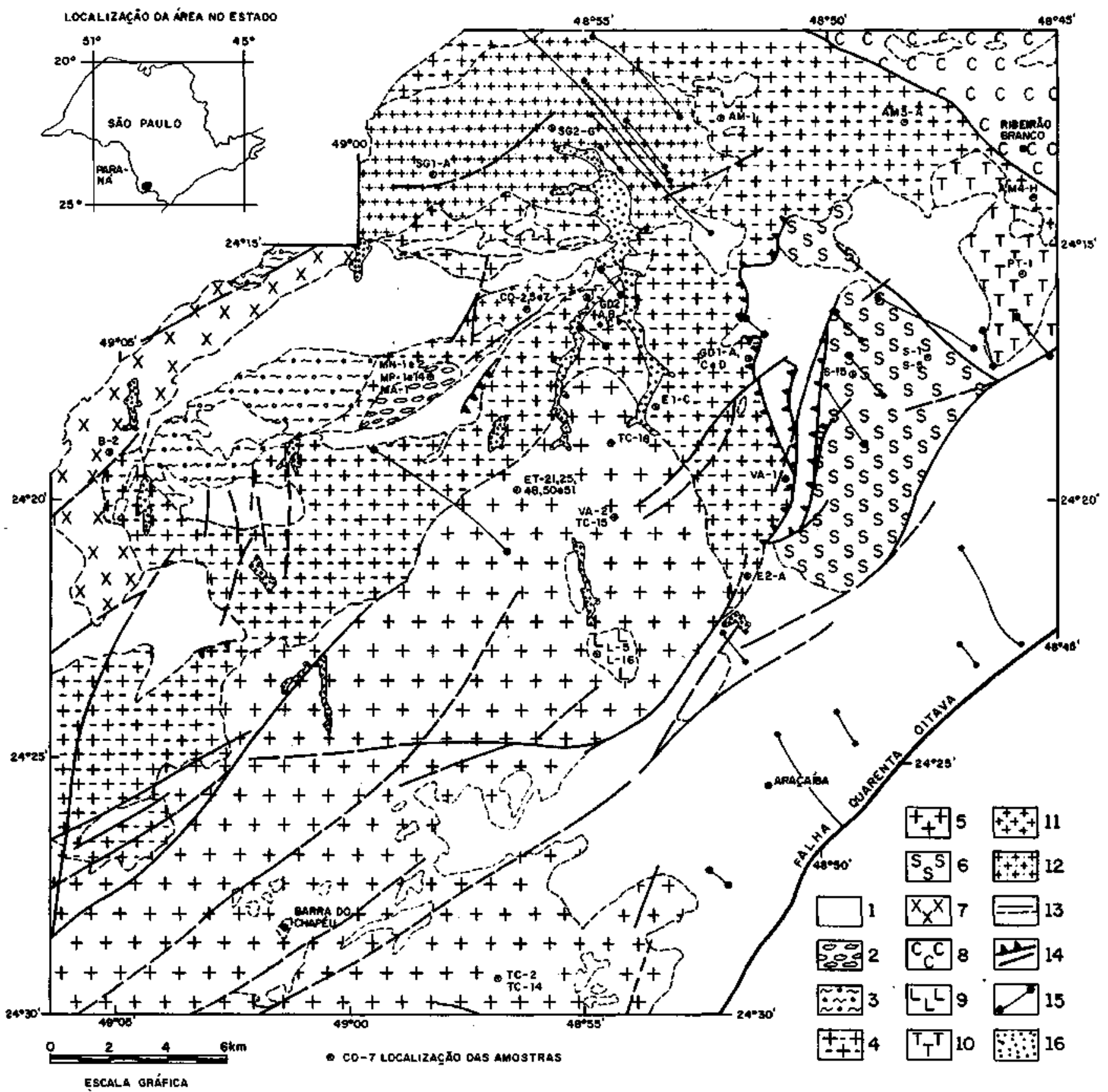

Figura 2 - Esboço geológico da área estudada e localização das amostras analisadas. Legenda: Unidades metassedimentares/metavulcanossedimentares (1); Augen Gnaisses (2); Complexo Granítico Três Córregos (3 a 10): Granitóides de Anatexia/Migmatitos (3), Granitóides Orientados (4), Granito Barra do Chapéu (5), Granito Saival (6), Granito Córrego do Butiá (7), Granito Capote (8), Granito Lajeado (9), Granito Paiol de Telha (10); Suíte Granítica Pós-Tectônica: Granito Correias (11) e Granito Sguário (12); contatos (13); falhas (14); diques de diabásio (15); aluviões (16)

Figure 2 - Geological sketch map of the studied area with sample location. Explanation: metasediments/vulcanosediments units (1); Augen Gneiss (2); Três Córregos Granitic Complex (3 to 1O): Anatetic Granitoids/Migmatites (3), Foliated Granitoids (4), Barra do Chapéu Granite (5), Saival Granite (6), Córrego do Butiá Granite (7), Capote Granite (8), Lajeado Granite (9), Paiol de Telha Granite (1O); Post-Tectonic Granitic Suit: Correias (11) and Sguário (12) Granites; boundary (13); faults (14); diabase dikes (15); aluvion (16)

Todas estas unidades foram englobadas como ortognaisses no Complexo Apiaí-Mirim por Campanha et al (1987) e por Campanha (1991).

Gimenez Filho (1993) readmitiu estes granitóides no Complexo Granítico Três Córregos "em função dos mesmos não apresentarem características marcantes que os diferenciem dos demais granitóides do complexo. Muito ao contrário, apresentam semelhanças composicionais (tanto em ter- mos mineralógicos quanto nas características geoquímicas), padrão geocronológico com faixas de idades muito próximas, mostram os mesmos tipos de enclaves quartzo monzodioríticos/quartzo dioríticos e, a exemplo dos outros granitóides do complexo, feições intrusivas nos metassedimentos encaixantes também foram observadas". A existência de maior grau de deformação em suas rochas justifica-se pela sua própria disposição cartográfica, geralmente como borda 
de outros corpos do complexo e, não raro, junto a importantes feições tectônicas.

Embora com ocorrência contínua (4, na Fig. 2), a maior área onde se observam estes granitóides é caracterizada pela existência de dois tipos com características distintas. O primeiro deles é representado pela maior ocorrência de granitóides porfiróides com biotita e hornblenda, sendo mais freqüentemente observado na porção nordeste da área, enquanto que na porção centro-sudoeste da área, passam a predominar granitóides mais claros (leucogranitóides), com menor incidência de máficos e de megacristais de feldspato alcalino.

Os contatos destes granitóides orientados com as unidades metassedimentares do Complexo Metamórfico ApiaíMirim (Chiodi Filho et al. 1983) e da Formação Água Clara (Marini et al. 1967), são bruscos, intrusivos, ou através de importantes feições tectônicas. Por exemplo, na porção centro-leste da área, tais granitóides estão empurrados por sobre as rochas calciossilicáticas, anfibolitos e quartzitos da Formação Agua Clara, com deformações intensas nos diversos litotipos envolvidos. Feições intrusivas destes Granitóides Orientados nas rochas calciossilicáticas e mármores impuros desta formação também são vistas naquela região.

Suite Porfiróide Esta suíte engloba os granitóides porfiróides mapeados na escala 1:50.000 por Bistrichi et al (1985) e Theodorovicz et al (1988), cujas denominações foram adotadas por tais autores.

Dentre os corpos estudados destaca-se, pela dimensão batolítica na porção centro-sudoeste da área estudada, o Granito Barra do Chapéu (5, na Fig. 2). Os demais granitos são menores em área de exposição, mas ainda assim abrangem grandes áreas. São os denominados Granito Saival (6), Granito Córrego do Butiá (7), Granito Capote (8), e o Granito Paiol de Telha (10, na Fig. 2).

Veios graníticos e/ou aplíticos, centimétricos a decimétricos, representando fase ou fases graníticas tardias, são observados em todos os granitos da suíte estudados. Tratam-se, em geral, de granitos de granulação média, localmente fina, cinza claro a médio, por vezes rosado.

Os contatos destes granitóides com as unidades metassedimentares são em geral bruscos e discordantes e, muitas vezes, tectônicos. Particularmente importantes são as feições observadas na borda oeste do Granito Saival, cujos contatos com as rochas calciossilicáticas da Formação Água Clara se dão por uma intrincada faixa de falhamentos por empurrão, onde as rochas calciossilicáticas são jogadas de oeste para leste por sobre o Granito Saival. Ali, veios graníticos injetados nas calciossilicáticas são deformados e a elas paralelizados, resultando num aspecto bandado do conjunto, com intercalações entre bandas graníticas/ aplíticas milonitizadas e bandas calciossilicáticas, também deformadas.

Granito Lajeado É o único Granito do Complexo Granítico Três Córregos que foge da característica principal (porfiróide) apresentada pelos demais. E caracterizado como um granito leucocrático, cinza claro (levemente rosado), microporfirítico, de granulação fina a média, com estrutura maciça e com incipiente orientação. Acha-se localizado na área do Granito Barra do Chapéu, porção centro-sul da área (9, Fig. 2), e seus contatos não foram observados.

Suíte Granítica Pós-Tectônica É constituída, na área estudada, pelos granitos Correias e Sguário (11 e 12, respectivamente, na Fig. 2) e, fora dela, pelo Granito Campina do Veado.

Granito Sguário Aparece no norte da área (Fig. 2) e foi cartografado por Theodorovicz et al (1988), que destaca- ram duas fácies, uma predominante, representada por granitos porfiróides e, outra, de menor expressão em área, situada na porção central do corpo, constituída por "microadamelitos".

Os contatos destes granitos com as encaixantes são intrusivos ou tectônicos, podendo aparecer feições migmáticas localizadas, com injeçôes de veios e/ou apófises graníticas. Nos limites por falha são comuns brechação e epidotizacão. Enclaves microgranulares são registrados localmente (Theodorovicz et al 1988).

Granito Correias É um corpo alongado de direção SSW-ENE, localizado na porção nor-noroeste da área, a sul do Granito Sguário e distante aproximadamente 2 a $3 \mathrm{~km}$ deste. E muito semelhante aos tipos porfiróides do Granito Sguário e, a exemplo deste, seus contatos são francamente intrusivos ou tectônicos. Brechas silicosas são observadas nos limites por falha e hornfels básicos foram observados, localmente, nas encaixantes (Goraieb et al 1987).

Granito Campina do Veado Este granito situa-se cerca de $10 \mathrm{~km}$ a norte-noroeste do Granito Sguário, ocorre em vales entalhados e acham-se descobertos e liberados da "capa" formada pela Bacia do Paraná. Foi aqui incluído para comparação com os demais granitos da Suíte, tendo sido também objeto de análises petrográfica e litoquímica.

ASPECTOS DE CAMPO E PETROGRÁFICOS

Augen Gnaisses Os augen gnaisses são rochas cinza claro a médio, de composição quartzo diorítica a quartzo monzodiorítica (Fig. 3), com cristais de plagioclásio ovalados em torno de um centímetro e raros cristais milimétricos de quartzo envoltos por uma matriz fina com quartzo, feldspato (plagioclásio e feldspato potássico), biotita e hornblenda. Plagioclásio representa, no total (mega cristais + matriz), em torno de $70 \%$ da rocha (Tab. 1). Os minerais acessórios principais são apatita, titanita, opacos e zircão, além de carbonato e epídoto.

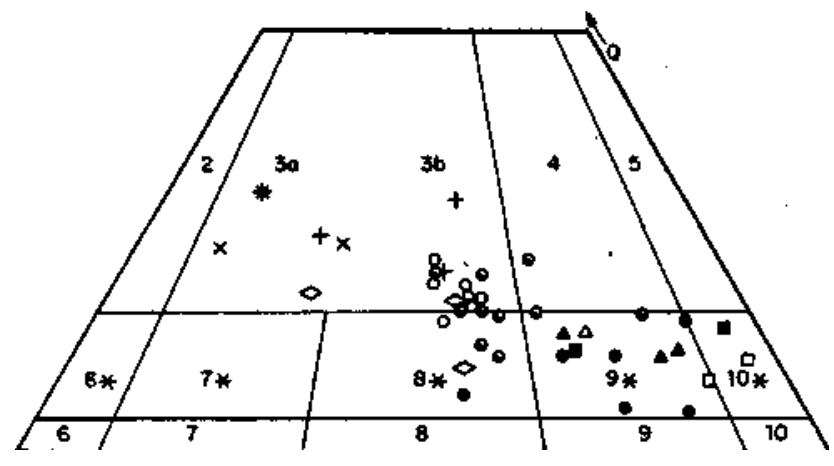

Figura 3 - Diagrama QAP com as amostras analisadas do Complexo Granitico Três Córregos, Símbolos: enclaves nos augen gnaisses (ם); augen gnaisses ( $\square)$; enclaves nos granitóides Três Córregos (•); granitóides Três Córregos com cerca de 67\% de silica (circulos semicheios); granitóides Três Córregos com cerca de $71 \%$ de silica $(\mathrm{O})$; enclaves nos granitóides orientados, com alto Al e baixo $\mathrm{Mg}$ (A.); granitóide Paiol de Telha (4); veios graniticos (+); granito Sguário (X); granito Correias (+); e granito Campina do Veado (*). Campos como em Streckeisen (1976) Figure 3 - QAP diagram with the analysed samples from the Três Córregos Granitic complex. Symbols: enclaves in the augen gneisses ( $\mathbf{\square})$; augen gneisses (D); enclaves in Três Córregos granitoids (•); Três Córregos granitoids with about $67 \%$ silica (half-filled circles); Três Córregos granitoids with about $71 \%$ silica $(0)$; enclaves in foliated granitoids, with high-Al and low-Mg (A); Paiol de Telha granitoid $(\Delta)$; granitic veins (4); Sguário granite $(\mathrm{X})$; Correias granite $(+)$; and Campina do Veado granite $(*)$. Fields as in Streckeisen (1976) 
Os enclaves escuros são gnaisses de granulação fina (a média, localmente), cinza médio-escuro a preto, de composição também quartzo diorítica a quartzo monzodiorítica (Fig. 3), com mineralogia dada por plagioclásio (aproximadamente $50 \%$ da rocha), quartzo, biotita, K-feldspato e hornblenda. Como minerais acessórios aparecem apatita, opacos, titanita, zircão e, mais raramente, carbonato e clorita (Tab. 1). Termos litológicos evidenciando uma aparente mistura entre este tipo petrográfíco e o descrito anteriormente (augen gnaisse) são observados localmente, resultando num aspecto bandado ao conjunto, com alternância irregular de bandas milimétricas a centimétricas, ora mais claras, ora mais escuras.

Os veios e diques róseos, que cortam os dois conjuntos anteriores, são de composição sienogranítica, constituídos por K-feldspato, plagioclásio e quartzo (amostra MA-1, na Tab. 1).

Tais veios podem aparecer cortando ou mesmo situaremse paralelos à foliação dos augen gnaisses e gnaisses finos, os quais, por sua vez, são concordantes e apresentam uma foliação gnáissica com direção variando entre N60W a leste-oeste, com mergulhos da ordem de $30^{\circ}$ a $60^{\circ}$ para sul. Veios pegmatíticos também são observados, menos freqüentemente.

Complexo Granítico Três Córregos Granitóides Orientados Os tipos predominantemente porfiróides (porção nordeste da área) são de composição granodiorítica (predominante) a monzogranítica no diagrama QAP (Fig. 3). São compostos por uma matriz de granulação média, cinza médio, em geral orientada (por vezes deformada), com quantidade variável de megacristais rosados de feldspato potássico concordantes, ou não, com a orientação da matriz. Os constituintes principais são plagioclásio, feldspato potássico, quartzo e biotita, além de hornblenda, em proporções bem inferiores. Opacos (magnetita), titanita, zircão e apatita são os acessórios mais comuns (Tab. 1). Nas porções mais deformadas nota-se forte epidotização. Veios graníticos mais finos, em geral cinza claro a médio, são freqüentes. Já veios e/ou bolsões pegmatíticos róseos, embora presentes, são mais raros. Em termos de aspectos gerais da rocha, estes granitóides são muito parecidos com os tipos observados no Granito Barra do Chapéu (Suíte Porfiróide).

$\mathrm{Na}$ porção centro-sudoeste da área, a principal ocorrência destes granitóides aparece circundando a área do Granito Barra do Chapéu. Nesta porção dos granitóides orientados, faixas fortemente deformadas são marcantes, como observado na sua borda NE, junto a importantes limites tectônicos, onde estes granitóides acham-se empurrados por sobre os metassedimentos da Formação Agua Clara.

Em geral os litotipos predominantes são granitóides rosados a cinza rosados claros, por vezes mesocráticos, de granulação média a grossa, com orientação desde incipiente a forte deformação (leucogranitóides cataclásticos são descritos), de composição predominantemente monzogranítica e constituídos por plagioclásio, K-feldspato e quartzo. Biotita e hornblenda raramente ultrapassam $5 \%$ da rocha, enquanto que opacos, titanita e apatita, além de clorita (que aparece associada à biotita) são os acessórios principais. Termos com megacristais de K-feldspato em torno de dois centímetros são também observados. Uma amostra de veio (VA-1) com análise petrográfica indicou tratar-se de monzogranito.

Suite Porfiróide Em geral estas rochas podem ser descritas como granitóides de granulação média a grossa, orientados ou não, cujo caráter porfiróide é dado pelo desenvolvimento de megacristais euédricos ou ovalados de $\mathrm{K}$-feldspato em meio a uma matriz de granulação média e cor cinza claro a médio (mesocrática), com textura predominantemente granular hipidiomórfica. Das análises petro- gráficas realizadas, em que se efetuou contagem de pontos (megacristais e matriz), obteve-se que estes granitóides são constituídos principalmente por monzogranitos (a maioria) e por quartzo monzonitos, além de granodioritos e quartzo monzodioritos, em menores proporções (Fig. 3). Como se pode verificar na Tabela 1, plagioclásio é o constituinte mineral de maior abundância, com teores que variam de 36 a $49 \%$, seguido por K-feldspato $(17$ a $36 \%$ ), quartzo (12 a $27 \%$ ), biotita (3 a 14\%) e hornblenda (2 a 9\%). Os minerais acessórios mais comuns são opacos (magnetita), titanita, zircão, apatita e clorita, esta freqüentemente associada à biotita. Muscovita-sericita, carbonato e epídoto podem aparecer, eventualmente.

Os megacristais de K-feldspato podem atingir 8 centímetros de eixo maior, com predominância das dimensões de até 3-4 cm, sendo freqüentes geminação Carlsbad e inclusões de biotita. A proporção de megacristais em relação à matriz é bastante variável, ora predominando megacristais, ora matriz, o que resulta em diferenças na grarjulação e na cor da rocha, ou seja, mais rosada e de granulação mais grossa e mais escura e de granulação mais fina, respectivamente.

Análise de uma amostra de veio, intrusivo no Granito Barra do Chapéu, indicou tratar-se de quartzo monzonito constituído por plagioclásio, K-feldspato, quartzo e biotita, além de hornblenda, opacos, titanita, zircão e apatita como acessórios.

Granito Lajeado As análises petrográficas realizadas indicaram tratar-se de monzogranitos (Fig. 3) microporfiríticos (megacristais de até um centímetro - raros maiores de microclínio micropertítico), constituídos por plagioclásio, K-feldspato, quartzo e biotita, esta em proporção não superior a $5 \%$ (Tab. 1). Os cristais de plagioclásio podem mostrar zoneamento, com bordas mais sódicas e límpidas, enquanto que a biotita acha-se alterada, parcial a totalmente, em clorita. Como minerais acessórios mais freqüentes aparecem opacos, titanita, zircão e apatita, além de, mais raramente, hornblenda, muscovita-sericita, clorita, carbonato e allanita.

Enclaves Os enclaves observados nos granitóides orientados e no Granito Barra do Chapéu (suíte porfiróide) são de dimensões variadas, de coloração cinza médio a escuro e podem ser considerados como básico-intermediários.

Petrograficamente são classificados como quartzo dioritos/quartzo monzodioritos a quartzo monzonitos gnáissicos (Fig. 3), com mineralogia dada por plagioclásio, K-feldspato, biotita, hornblenda e quartzo. Em algumas amostras, o quartzo aparece em proporções um pouco superiores à hornblenda e à biotita (Tab. 1). Dentre os minerais acessórios mais comuns aparecem opacos, titanita, zircão e apatita. Carbonato e epídoto também podem estar presentes.

Suíte Granítica Pós-Tectônica Granito Sguário Os granitos porfiróides, predominantes, são cinza rosados claros a avermelhados, de estrutura maciça, de granulação média a grossa, por vezes destacando-se megacristais maiores (até 2-3 cm) de K-feldspato pertítico e agregados ou mesmo cristais de aproximadamente um centímetro de quartzo, o que dá o aspecto porfiróide à rocha. Composicionalmente situam-se no limite dos campos sienogranito/ monzogranito (Fig. 3) e os minerais constituintes principais são K-feldspato, quartzo e plagioclásio, com biotita (marrom, parcialmente cloritizada) apresentando teores em torno de 5-6\% (Tab. 1). Os minerais acessórios são: magnetita, titanita, zircão, apatita e allanita. Carbonato e/ou fluorita podem aparecer em microvênulas e sericita, epídoto e clorita, como minerais secundários.

Os microadamelitos são de granulação média a fina, onde aparecem dois extremos em cor: um tipo predominante, cinza claro a médio, e outro avermelhado a vermelho 
Tabela 1 - Análises petrográfícas modais. KF = feldspato potássico; PL - plagioclásio; QZ - quartzo; BI - biotita; $H B$ - hornblenda; $O=$ opacos; $T$ - titanita; $Z=$ zircão; $A=$ apatita; $M$ - muscovita/sericita; $C=$ carbonato; $E=$ epidoto; $C L=$ clorita $; Q A P$ - campos no diagrama $Q A P ; N=$ número de pontos; $t$ - traços

Table 1 - Modal petrographic analyses. $\mathrm{KF}=$ alkali feldspar; $\mathrm{PL}=$ plagioclase; $\mathrm{QZ}=$ quartz; $\mathrm{BI}=$ biotite; $\mathrm{HB}=$ hornblende; $\mathrm{O}=$ opaque minerals; $\mathrm{T}=$ titanite; $\mathrm{Z}=$ zircon; $\mathrm{A}=$ apatite; $\mathrm{M}=$ muscovite/serícite; $\mathrm{C}=$ carbonate; $\mathrm{E}=$ epidote; $\mathrm{CL}=$ chlorite; $\mathrm{QAP}=$ position in $\mathrm{QAP}$ diagram fields; $\mathrm{N}=$ number of points; $\mathrm{t}=$ trace

\begin{tabular}{|c|c|c|c|c|c|c|c|c|c|c|c|c|c|c|c|c|c|c|}
\hline \multicolumn{3}{|c|}{ LITOTIPOS } & AMOSTRAS & $\mathbf{K F}$ & PL & $\mathbf{Q Z}$ & BI & HB & 0 & $\mathbf{T}$ & $\mathbf{z}$ & $\mathbf{A}$ & $\mathbf{M}$ & $\mathbf{C}$ & $\mathbf{E}$ & CL & QAP & $\mathbf{N}$ \\
\hline \multicolumn{3}{|c|}{$\begin{array}{c}\text { AUGEN } \\
\text { ONAISSES }\end{array}$} & $\begin{array}{l}\text { MN-1 } \\
\text { MN-2 }\end{array}$ & $\begin{array}{l}9 \\
3\end{array}$ & $\begin{array}{l}73 \\
68\end{array}$ & $\begin{array}{r}9 \\
11\end{array}$ & $\begin{array}{r}6 \\
11\end{array}$ & $\begin{array}{l}3 \\
6\end{array}$ & t & t & t & t & - & $\begin{array}{l}\mathrm{t} \\
-\end{array}$ & 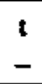 & - & $\begin{array}{l}9 * \\
10^{*}\end{array}$ & $\begin{array}{l}1619 \\
1431\end{array}$ \\
\hline \multicolumn{3}{|c|}{$\begin{array}{l}\text { GNAISSES } \\
\text { FINOS }\end{array}$} & $\begin{array}{c}\text { MP-1 } \\
\text { MP-14 }\end{array}$ & $\begin{array}{r}21 \\
3\end{array}$ & $\begin{array}{l}54 \\
52\end{array}$ & $\begin{array}{l}13 \\
12\end{array}$ & $\begin{array}{r}8 \\
14\end{array}$ & $\begin{array}{r}3 \\
19\end{array}$ & t & $\begin{array}{l}1 \\
-\end{array}$ & t & t & - & $\begin{array}{l}t \\
-\end{array}$ & - & $\bar{t}$ & $\begin{array}{l}9 * \\
10^{*}\end{array}$ & $\begin{array}{c}978 \\
1046 \\
\end{array}$ \\
\hline \multicolumn{3}{|c|}{ VEIO GRANITICO } & MA-I & 52 & 25 & 23 & $t$ & - & $t$ & - & - & - & 1 & - & - & $\mathbf{t}$ & $3 a$ & 270 \\
\hline \multirow{2}{*}{$\begin{array}{c}\text { C } \\
0 \\
\text { M } \\
\text { P } \\
\text { L } \\
\text { E } \\
\text { X } \\
0\end{array}$} & $\begin{array}{l}\mathbf{S} \\
\mathbf{U} \\
\mathbf{f} \\
\mathbf{T} \\
\mathrm{E}\end{array}$ & $\begin{array}{l}\text { GRANITOIDES } \\
\text { ORIENTADOS }\end{array}$ & $\begin{array}{c}\text { Aml } \\
\text { Am4-H } \\
\text { Am3-A } \\
\text { E1-C } \\
\text { E2-A }\end{array}$ & $\begin{array}{l}30 \\
20 \\
11 \\
29 \\
32\end{array}$ & $\begin{array}{l}41 \\
43 \\
56 \\
43 \\
43 \\
\end{array}$ & $\begin{array}{l}19 \\
24 \\
17 \\
25 \\
22\end{array}$ & $\begin{array}{r}7 \\
10 \\
11 \\
1 \\
2\end{array}$ & $\begin{array}{l}2 \\
3 \\
3 \\
1 \\
1\end{array}$ & $\begin{array}{l}1 \\
1 \\
1 \\
t \\
t\end{array}$ & $\begin{array}{l}t \\
t \\
1 \\
t\end{array}$ & $\begin{array}{l}t \\
t \\
t \\
t \\
-\end{array}$ & $\begin{array}{l}t \\
t \\
t \\
1\end{array}$ & $\begin{array}{l}- \\
- \\
- \\
-\end{array}$ & $\begin{array}{l}t \\
- \\
t \\
- \\
-\end{array}$ & $\begin{array}{l}- \\
- \\
- \\
-\end{array}$ & $\begin{array}{l}t \\
t \\
t \\
1 \\
t\end{array}$ & $\begin{array}{c}\mathbf{3 b} \\
\mathbf{4} \\
4 \\
\mathbf{3 b} \\
\mathbf{3 b} \\
\end{array}$ & $\begin{array}{c}297 \\
430 \\
1094 \\
29 \\
322 \\
\end{array}$ \\
\hline & \multirow{4}{*}{$\begin{array}{l}\mathbf{P} \\
\mathbf{O} \\
\mathbf{R} \\
\mathbf{F} \\
\mathbf{I} \\
\mathbf{R} \\
\mathbf{0} \\
\mathbf{I} \\
\mathbf{D} \\
\mathbf{E}\end{array}$} & $\begin{array}{c}\text { GRANTO } \\
\text { BARRA } \\
\text { DO } \\
\text { CHAPÉU }\end{array}$ & $\begin{array}{l}\text { TC-2 } \\
\text { TC-14 } \\
\text { TC-15 } \\
\text { TC-16 } \\
\text { ET-48 } \\
\text { ET-50 }\end{array}$ & $\begin{array}{l}30 \\
21 \\
32 \\
31 \\
29 \\
28 \\
\end{array}$ & $\begin{array}{l}42 \\
43 \\
36 \\
39 \\
41 \\
45 \\
\end{array}$ & $\begin{array}{l}13 \\
16 \\
24 \\
19 \\
18 \\
18 \\
\end{array}$ & $\begin{array}{r}14 \\
8 \\
4 \\
6 \\
7 \\
4 \\
\end{array}$ & $\begin{array}{l}- \\
9 \\
3 \\
3 \\
3 \\
5 \\
\end{array}$ & $\begin{array}{l}t \\
t \\
1 \\
1 \\
1 \\
t\end{array}$ & $\begin{array}{l}1 \\
1 \\
t \\
1 \\
1 \\
t\end{array}$ & $\begin{array}{l}1 \\
1 \\
1 \\
1 \\
t\end{array}$ & $\begin{array}{l}t \\
t \\
t \\
t \\
t \\
t\end{array}$ & $\begin{array}{l}- \\
- \\
- \\
1 \\
1\end{array}$ & $\begin{array}{l}- \\
- \\
- \\
- \\
1\end{array}$ & $\begin{array}{l}- \\
- \\
- \\
-\end{array}$ & $\begin{array}{l}- \\
- \\
1 \\
1 \\
-\end{array}$ & $\begin{array}{c}8 * \\
4 \\
3 b \\
3 b \\
3 b \\
3 b\end{array}$ & $\begin{array}{l}250 \\
332 \\
526 \\
203 \\
525 \\
238 \\
\end{array}$ \\
\hline \multirow{3}{*}{$\begin{array}{c}\mathbf{G} \\
\mathbf{R} \\
\mathbf{A} \\
\mathbf{N} \\
\mathbf{f} \\
\mathbf{T} \\
\mathbf{I} \\
\mathbf{C} \\
\mathbf{O}\end{array}$} & & $\begin{array}{c}\text { GRANITO } \\
\text { SAIVAL }\end{array}$ & $\begin{array}{l}\text { S-1 } \\
\text { S-5 } \\
\text { S-15 }\end{array}$ & $\begin{array}{l}30 \\
36 \\
29\end{array}$ & $\begin{array}{l}44 \\
41 \\
45\end{array}$ & $\begin{array}{l}21 \\
18 \\
12\end{array}$ & $\begin{array}{l}3 \\
3 \\
7\end{array}$ & $\begin{array}{l}2 \\
2 \\
6\end{array}$ & $\begin{array}{l}t \\
1 \\
\text { l }\end{array}$ & $\begin{array}{l}t \\
t \\
t\end{array}$ & $\begin{array}{l}t \\
t \\
t\end{array}$ & $\begin{array}{l}t \\
1 \\
1\end{array}$ & - & $\begin{array}{l}t \\
- \\
-\end{array}$ & - & $\begin{array}{l}t \\
t \\
t\end{array}$ & $\begin{array}{l}3 b \\
8^{*} \\
8^{*}\end{array}$ & $\begin{array}{l}385 \\
313 \\
551\end{array}$ \\
\hline & & GR.C.DO BUTIA & B-2 & 30 & 40 & 22 & 5 & 2 & $\mathbf{t}$ & t & $t$ & $\mathbf{t}$ & 1 & - & $\mathbf{t}$ & $\mathbf{t}$ & $3 \mathrm{~b}$ & 352 \\
\hline & & GR.P.DE TELHA & PT-1 & 17 & 49 & 14 & 10 & 8 & $\mathbf{1}$ & 1 & - & $\mathbf{t}$ & - & - & - & $\mathbf{t}$ & 9* & 316 \\
\hline \multirow{2}{*}{$\begin{array}{l}T \\
R \\
E \\
S\end{array}$} & \multirow{4}{*}{$\begin{array}{l}\mathbf{E} \\
\mathbf{N} \\
\mathbf{C} \\
\mathrm{L} \\
\mathrm{A} \\
\mathrm{V} \\
\mathrm{E} \\
\mathrm{S}\end{array}$} & $\begin{array}{l}\text { GRANITO } \\
\text { LAJEADO }\end{array}$ & $\begin{array}{l}\text { L-S } \\
\text { L-16 }\end{array}$ & $\begin{array}{l}34 \\
34\end{array}$ & $\begin{array}{l}37 \\
37\end{array}$ & $\begin{array}{l}27 \\
23\end{array}$ & $\begin{array}{l}1 \\
5\end{array}$ & t & t & t & $\begin{array}{l}t \\
t\end{array}$ & t & $\begin{array}{l}1 \\
-\end{array}$ & $\begin{array}{l}1 \\
-\end{array}$ & - & 1 & $\begin{array}{l}3 \mathrm{~b} \\
3 \mathrm{~b}\end{array}$ & $\begin{array}{l}431 \\
422\end{array}$ \\
\hline & & $\begin{array}{c}\text { VEIOS } \\
\text { GRANITICOS }\end{array}$ & $\begin{array}{l}\text { VA-1 } \\
\text { VA-2 }\end{array}$ & $\begin{array}{l}33 \\
35\end{array}$ & $\begin{array}{l}41 \\
44\end{array}$ & $\begin{array}{l}21 \\
11\end{array}$ & $\begin{array}{l}2 \\
7\end{array}$ & $\begin{array}{l}2 \\
1\end{array}$ & t & 1 & t & - & - & - & $\begin{array}{l}t \\
-\end{array}$ & 1 & $\begin{array}{l}3 \mathrm{~b} \\
8 *\end{array}$ & $\begin{array}{l}291 \\
401\end{array}$ \\
\hline \multirow{2}{*}{$\begin{array}{c}C \\
0 \\
R \\
R \\
E \\
G \\
0 \\
S\end{array}$} & & $\begin{array}{c}\text { NO GRANITO } \\
\text { BARRA DO } \\
\text { CHAPÉU }\end{array}$ & $\begin{array}{l}\text { ET-21 } \\
\text { ET-25 } \\
\text { ET-51 }\end{array}$ & $\begin{array}{r}5 \\
9 \\
19\end{array}$ & $\begin{array}{l}46 \\
50 \\
44\end{array}$ & $\begin{array}{r}12 \\
4 \\
10\end{array}$ & $\begin{array}{r}10 \\
15 \\
9\end{array}$ & $\begin{array}{l}17 \\
20 \\
14\end{array}$ & $\begin{array}{l}2 \\
1 \\
2\end{array}$ & $\begin{array}{l}1 \\
2 \\
2\end{array}$ & $\begin{array}{l}t \\
t \\
-\end{array}$ & $\begin{array}{l}1 \\
t \\
t\end{array}$ & $\begin{array}{l}- \\
- \\
-\end{array}$ & $\begin{array}{l}2 \\
t \\
t\end{array}$ & $\begin{array}{l}4 \\
- \\
-\end{array}$ & $\begin{array}{l}- \\
- \\
-\end{array}$ & $\begin{array}{l}9 * \\
9 * \\
9 *\end{array}$ & $\begin{array}{l}1034 \\
1100 \\
1104\end{array}$ \\
\hline & & $\begin{array}{c}\text { NOS } \\
\text { GRANITOIDES } \\
\text { ORIENTADOS }\end{array}$ & $\begin{array}{l}\text { GD1-A } \\
\text { GD1-C } \\
\text { GD1-D } \\
\text { GD2-A } \\
\text { GD2-B } \\
\text { GD2-C }\end{array}$ & $\begin{array}{r}16 \\
30 \\
10 \\
11 \\
9 \\
22\end{array}$ & $\begin{array}{l}53 \\
37 \\
34 \\
60 \\
58 \\
53\end{array}$ & $\begin{array}{r}5 \\
6 \\
7 \\
12 \\
12 \\
16\end{array}$ & $\begin{array}{r}13 \\
12 \\
18 \\
13 \\
15 \\
6\end{array}$ & $\begin{array}{r}13 \\
13 \\
27 \\
4 \\
4 \\
3\end{array}$ & $\begin{array}{l}1 \\
2 \\
2 \\
1 \\
1 \\
1\end{array}$ & $\begin{array}{l}1 \\
1 \\
2 \\
t \\
1 \\
1\end{array}$ & $\begin{array}{l}t \\
t \\
t \\
t \\
t \\
t\end{array}$ & $\begin{array}{l}1 \\
1 \\
1 \\
1 \\
1 \\
\end{array}$ & $\begin{array}{l}- \\
- \\
- \\
- \\
-\end{array}$ & $\begin{array}{l}- \\
- \\
- \\
t \\
1 \\
-\end{array}$ & $\begin{array}{l}1 \\
1 \\
- \\
1 \\
-\end{array}$ & $\begin{array}{l}- \\
- \\
- \\
- \\
-\end{array}$ & $\begin{array}{l}9^{*} \\
8^{*} \\
9^{*} \\
9^{*} \\
9^{*} \\
9^{*}\end{array}$ & $\begin{array}{l}1103 \\
1103 \\
1019 \\
1128 \\
1001 \\
1029\end{array}$ \\
\hline \multirow{3}{*}{\multicolumn{2}{|c|}{$\begin{array}{l}\text { SUfTE } \\
\text { PÓs- } \\
\text { TECTÓ. } \\
\text { NICA }\end{array}$}} & $\begin{array}{l}\text { GRANITO } \\
\text { SGUARIO }\end{array}$ & $\begin{array}{l}\text { Sg]-A } \\
\text { Sgz-G }\end{array}$ & $\begin{array}{l}42 \\
58 \\
\end{array}$ & $\begin{array}{l}24 \\
10\end{array}$ & $\begin{array}{l}28 \\
28 \\
\end{array}$ & $\begin{array}{l}6 \\
4\end{array}$ & - & t & 1 & - & t & t & - & t & $t$ & $\begin{array}{l}3 \mathrm{~b} \\
3 \mathrm{a} \\
\end{array}$ & $\begin{array}{l}358 \\
155 \\
\end{array}$ \\
\hline & & $\begin{array}{l}\text { GRANITO } \\
\text { CORREIAS }\end{array}$ & $\begin{array}{l}\mathrm{CO}-2 \\
\mathrm{CO}-5 \\
\mathrm{CO}-7\end{array}$ & $\begin{array}{l}33 \\
26 \\
44 \\
\end{array}$ & $\begin{array}{l}38 \\
34 \\
21 \\
\end{array}$ & $\begin{array}{l}25 \\
34 \\
29\end{array}$ & $\begin{array}{l}2 \\
- \\
2\end{array}$ & $\begin{array}{l}- \\
- \\
-\end{array}$ & t & $\begin{array}{l}1 \\
- \\
-\end{array}$ & $\begin{array}{l}- \\
- \\
-\end{array}$ & $\begin{array}{l}- \\
\text { t }\end{array}$ & $\begin{array}{l}1 \\
3 \\
3 \\
\end{array}$ & $\begin{array}{l}- \\
1 \\
-\end{array}$ & $\begin{array}{l}1 \\
- \\
-\end{array}$ & $\begin{array}{l}1 \\
3 \\
1 \\
\end{array}$ & $\begin{array}{l}3 b \\
3 a \\
3 b\end{array}$ & $\begin{array}{l}325 \\
360 \\
384 \\
\end{array}$ \\
\hline & & GR.C.DO VEADO & CV-1 & 51 & 12 & 37 & - & - & - & - & - & - & t & $t$ & - & t & 3a & 245 \\
\hline
\end{tabular}

carne. Podem ser considerados, pelo menos localmente, como microporfíríticos, pela existência de megacristais (até $1 \mathrm{~cm}$ ) de K-feldspato e quartzo em meio à rocha mais fina. A composição é sienogranítica, dada por K-feldspato, quartzo, plagioclásio e biotita, esta em proporções inferiores a $5 \%$. Os minerais acessórios são: apatita, magnetita, muscovita-sericita (secundária), epidoto e clorita (Tab. 1).
Granito Correias Constitui-se de granito inequigranular, de granulação média a grossa, cinza rosado a avermelhado, com textura porfirítica representada por megacristais de K-feldspato (microclínio pertítico) de até $3 \mathrm{~cm}$ e também por quartzo (agregado?) de até um centímetro. Composicionalmente variam de monzogranitos a sienogranitos (Fig. 3) e seus constituintes principais são K-feldspato, plagioclásio 
e quartzo que, somados, atingem, 95\% da rocha. Em seguida aparecem biotita parcialmente cloritizada, clorita, muscovita-sericita (secundária), opacos, carbonato e apatita (Tab. 1).

Granito Campina do Veado É constituído por granitos de estrutura maciça, inequigranulares, localmente porfiríticos, de textura granular hipidiomórfica, de composição sienogranítica (Fig. 3), cuja mineralogia é dada por $\mathrm{K}$-feldspato (cerca de $50 \%$ ), quartzo, plagioclásio e pequenas manchas de biotita cloritizada (Tab. 1). Como traços aparecem opacos, clorita, muscovita-sericita (secundária) e carbonato.

LITOGEOQUÍMICA Os dados analíticos das 40 amostras analisadas constam das tabelas 2 e 3 .

Além das 40 amostras da área, foram analisadas duas outras (Tab. 4), cujos dados químicos já haviam sido anteriormente obtidos através de análises nos laboratórios do Departament of Earth Sciences da Memorial University of Newfoundland, Canadá, com os óxidos sendo dosados por absorção atômica após ataque ácido em bombas de teflon e os elementos traços por fluorescência de raios $\mathrm{X}$, com o objetivo de se ter uma avaliação comparativa dos dados obtidos. A boa qualidade dos dados canadenses tem sido confirmada por outras re-análises no Imperial College, Inglaterra, e no Activation Laboratories, Canadá.

Tratamento e Interpretação dos Dados Obtidos Diagramas de variação dos óxidos, como os que utilizam o índice de Harker (e.g., Fig. 4), mostram que há uma boa coerência composicional entre os granitóides Três Córregos e seus enclaves, o que também ocorre com os granitóides orientados e alguns de seus enclaves, que se distribuem geralmente como uma tendência retilínea expandida e com pouca dispersão de dados, parecendo caracterizar uma seqüência cogenética. A exceção que se observa (Fig. 4) refere-se aos teores ligeiramente mais elevados de $\mathrm{MgO}$ para os enclaves relativamente à tendência dos granitóides Três Córregos.

Observando mais atentamente a seqüência Três Córregos, nota-se que os enclaves são básico-intermediários, enquanto os granitóides orientados, Barra do Chapéu e Saival podem ser subdivididos em dois conjuntos, com teores de silica da ordem de $67 \%$ e $71 \%$, respectivamente. Esses dois conjuntos representam os granitóides porfiróides com biotita e hornblenda, por um lado, e leucogranitóides, por outro lado, descritos anteriormente. Uma única amostra de granitóide Barra do Chapéu (TC-14) tem composição intermediária, com $60 \%$ de silica, comparável aos termos mais diferenciados dos enclaves. Os granitos Córrego do Butiá e Lajeado, aqui analisados, definiram apenas as composições leucogranitóides (aproximadamente com $71 \%$ de silica).

Com tendência composicional distinta, ocorrem alguns enclaves nos granitóides orientados (GD2-A, GD2-B e GD2C), que apresentam composições mais assemelhadas à do granitóide Paiol de Telha (PT-1), sendo relativamente enriquecidos em alumina e empobrecidos em MgO (Fig. 4).

Os augen gnaisses são bastante diferentes, sendo mais pobres em $\mathrm{Fe}, \mathrm{Ti}, \mathrm{Mg}, \mathrm{K}$ e $\mathrm{P}$ e mais ricos em $\mathrm{Al}$ e $\mathrm{Na}$, comparados aos granitóides porfiróides e seus enclaves. Das duas amostras de enclaves de gnaisses finos, coletadas nos augen gnaisses, uma (MP-1) parece ter mais afinidade com o grupamento dos enclaves GD2 e granitóide Paiol de Telha, enquanto a outra (MP-14) é bem mais rica em $\mathrm{Mg}$ e mais pobre em $\mathrm{Al}$ (Fig. 4).

Os granitos pós-tectônicos Sguário, Correias e Campina do Veado são mais silicosos e apresentam composições levemente diferentes daquelas dos termos mais diferencia-

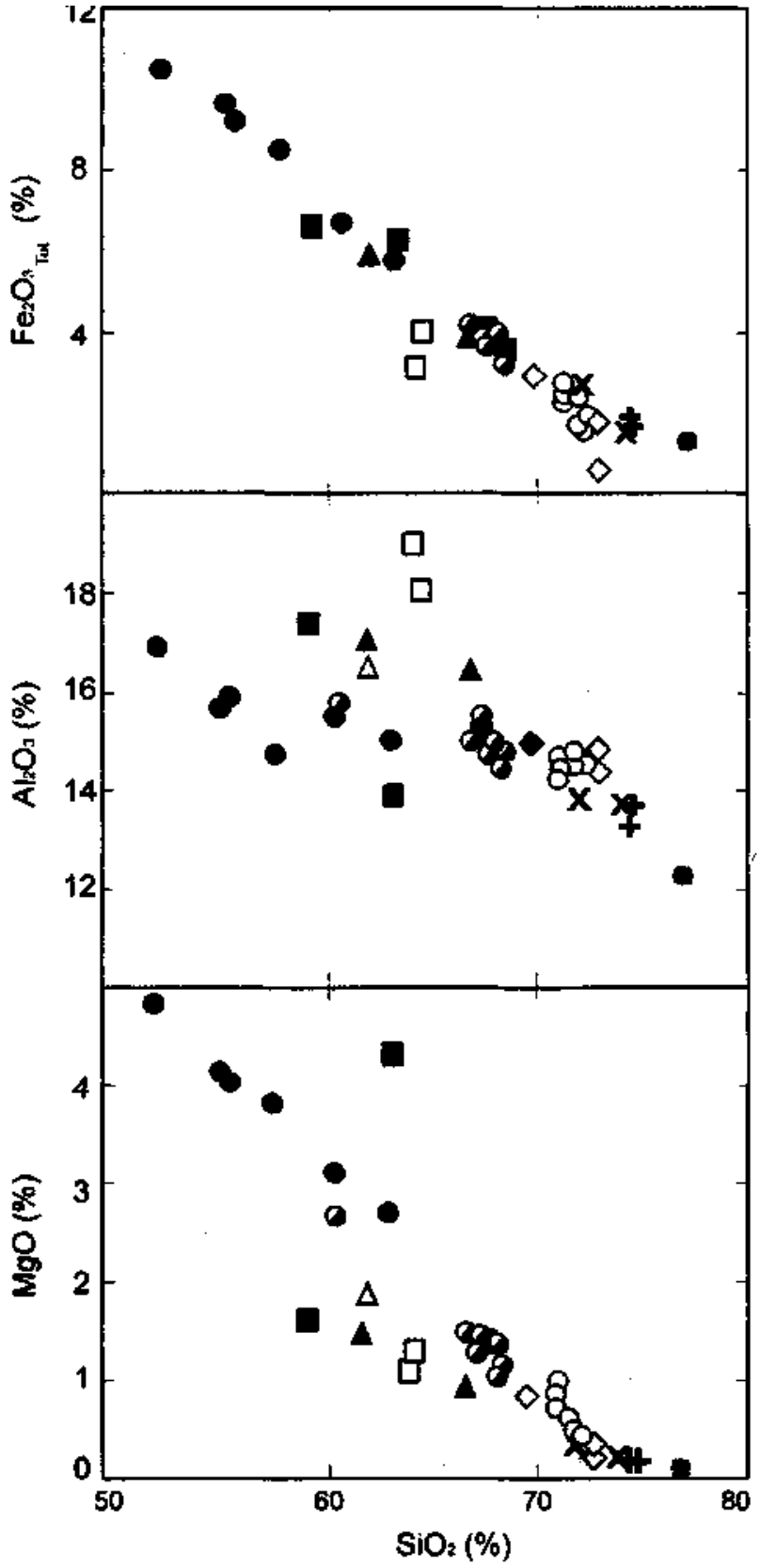

Figura 4 - Diagrama de Harker para ferro total (como $\mathrm{Fe}_{2} \mathrm{O}_{3}$ ), $\mathrm{Al}_{2} \mathrm{O}_{3}$ e $\mathrm{MgO}$ para as amostras analisadas. Mesma simbologia da Fig. 3

Figure 4 - Harker diagram for $\mathrm{Fe}_{2} \mathrm{O}_{3}$ as total iron, alumina and $\mathrm{MgO}$ for the analysed samples. Symbols as in Fig. 3

dos da seqüência Três Córregos, como teores relativamente mais baixos de $\mathrm{Na}$ e $\mathrm{Al}$ e mais altos de $\mathrm{K}$ e $\mathrm{Fe}$.

As três amostras de veios graníticos investigadas assemelham-se às composições dos leucogranitóides Três Córregos, embora possam também ter algumas características dos granitos pós-tectônicos, como será visto adiante.

No diagrama P-Q de Debon \& Lê Fort (1983), exibido na Figura 5, observa-se que a seqüência Três Córregos caracteriza uma tendência monzogabro-monzodiorito-quartzomonzonito-granodiorito-adamelito, enquanto os augen gnaisses correspondem a quartzo-dioritos e os granitos póstectônicos caem no campo dos granitos propriamente ditos. A seqüência Três Córregos apresenta um índice de Peacock (1931) de 54, o que a define como sendo uma suíte álcali- 
Tabela 2 - Dados de elementos maiores, menores (\% em peso dos óxidos) e traços (em ppm) das análises químicas efetuadas. Para verificar o litotipo analisado, veja a Tab. $l$

Table 2 - Major and trace element data. To relate sample and geologic unit, see Tab. 1

\begin{tabular}{|c|c|c|c|c|c|c|c|c|c|c|c|c|c|c|c|c|c|c|c|c|}
\hline \multirow[b]{2}{*}{$\begin{array}{l}\mathrm{SOO}_{2} \\
\mathrm{TiO}_{2} \\
\mathrm{Al}_{2} \mathrm{O}_{3} \\
\mathrm{Fe}_{2} \mathrm{O}_{3} \\
\mathrm{FeO}_{3} \\
\mathrm{MnO} \\
\mathrm{MgO} \\
\mathrm{COO} \\
\mathrm{Ne}_{2} \mathrm{O} \\
\mathrm{K}_{2} \mathrm{O} \\
\mathrm{P}_{1} \mathrm{O}_{3} \\
\mathrm{~F} \\
\mathrm{P} . \mathrm{F} .\end{array}$} & MP-1 & MP-14 & MN-1 & MN-2 & GDI-A & GDl-C & GDI-D & GD2A & GD2-B & GD2.C & ET-21 & ET-25 & ET-S1 & Aml & $\mathrm{Am} \mathrm{B}^{3}-\mathrm{A}$ & $A m A H$ & El-C & E2-A & ET-48 & ET 50 \\
\hline & $\begin{array}{r}58,70 \\
0.85 \\
17,30 \\
4,10 \\
2,30 \\
0,10 \\
1,60 \\
1,60 \\
4,50 \\
4,30 \\
0,45 \\
0.15 \\
0.62\end{array}$ & $\begin{array}{r}62,30 \\
0,62 \\
13,80 \\
2,30 \\
3,70 \\
0,10 \\
4,30 \\
5,00 \\
3,40 \\
2,30 \\
0,41 \\
0,22 \\
1,15\end{array}$ & $\begin{array}{r}63,40 \\
0,31 \\
18,90 \\
1,30 \\
1,70 \\
0,05 \\
1,10 \\
4,00 \\
5,90 \\
2,10 \\
0,10 \\
0,073 \\
0,64\end{array}$ & $\begin{array}{r}63,70 \\
0,40 \\
18,00 \\
1,90 \\
2,00 \\
0,06 \\
1,30 \\
4,00 \\
5,70 \\
1,70 \\
0,14 \\
0,082 \\
0,57\end{array}$ & $\begin{array}{r}60,10 \\
0,90 \\
15,60 \\
3,50 \\
3,00 \\
0,09 \\
3,10 \\
4,80 \\
3,50 \\
4,00 \\
0,30 \\
0,099 \\
0,50\end{array}$ & $\begin{array}{r}62,40 \\
0,78 \\
14,90 \\
2,80 \\
2,80 \\
0,08 \\
2,70 \\
4,30 \\
3,40 \\
4,20 \\
0,27 \\
0.10 \\
0,94\end{array}$ & $\begin{array}{r}51,70 \\
\mathbf{1 , 4 0} \\
\mathbf{1 6 , 8 0} \\
4,50 \\
5,40 \\
0,12 \\
4,90 \\
7,60 \\
3,40 \\
2,40 \\
0,53 \\
0,20 \\
0,58\end{array}$ & $\begin{array}{r}\mathbf{6 1 , 2 0} \\
0,74 \\
\mathbf{1 7 , 0 0} \\
2,10 \\
3,50 \\
0,08 \\
1,50 \\
4,40 \\
3,00 \\
4,00 \\
0,27 \\
0,14 \\
0,91\end{array}$ & $\begin{array}{r}61,00 \\
0,75 \\
16,90 \\
2,60 \\
3,10 \\
0,07 \\
1,50 \\
4,60 \\
3,50 \\
4,10 \\
0,29 \\
0,21 \\
0,96\end{array}$ & $\begin{array}{r}66,00 \\
0,53 \\
16,40 \\
2,30 \\
1,50 \\
0,05 \\
0,95 \\
2,90 \\
3,70 \\
4,40 \\
0,18 \\
0,064 \\
0.71\end{array}$ & $\begin{array}{r}54,60 \\
1,30 \\
15,70 \\
4,00 \\
4,20 \\
0,11 \\
4,00 \\
6,10 \\
3,50 \\
3,40 \\
0,57 \\
0,30 \\
1,15\end{array}$ & $\begin{array}{r}54,40 \\
1,40 \\
15,60 \\
4,70 \\
4,40 \\
0,12 \\
4,10 \\
6,0 \\
3,40 \\
3,50 \\
0,56 \\
0,25 \\
0,83\end{array}$ & $\begin{array}{r}56,90 \\
1,20 \\
14,70 \\
3,80 \\
4,20 \\
0,11 \\
3,80 \\
5,80 \\
3,40 \\
3,80 \\
0.55 \\
0.23 \\
0,94\end{array}$ & $\begin{array}{r}67,60 \\
0,52 \\
14,90 \\
1,90 \\
1,70 \\
0,06 \\
1,10 \\
3,00 \\
3,50 \\
4,60 \\
0,18 \\
0,085 \\
0,45\end{array}$ & $\begin{array}{r}\mathbf{6 6 , 5 0} \\
0,54 \\
\mathbf{1 5 , 2 0} \\
1,90 \\
2,00 \\
0,07 \\
1,50 \\
3,50 \\
3,70 \\
3,60 \\
0.16 \\
0,09 \\
0,84\end{array}$ & $\begin{array}{r}67,10 \\
0,57 \\
14,80 \\
1,90 \\
2,00 \\
0,06 \\
1,40 \\
3,00 \\
3,50 \\
4,50 \\
0.19 \\
0.14 \\
0.57\end{array}$ & $\begin{array}{r}71,60 \\
0,22 \\
14,60 \\
0,91 \\
0,98 \\
0,03 \\
0,43 \\
1,60 \\
4,70 \\
4,20 \\
0,10 \\
0.08 \\
0,43\end{array}$ & $\begin{array}{r}70,70 \\
0,29 \\
14,60 \\
0,96 \\
1,30 \\
0,05 \\
0,69 \\
1,90 \\
4,50 \\
4,00 \\
0,12 \\
0.07 \\
0.52\end{array}$ & $\begin{array}{r}\mathbf{6 7 , 7 0} \\
0,53 \\
\mathbf{1 4 , 9 0} \\
1,70 \\
1,70 \\
0,05 \\
1,20 \\
2,80 \\
3,90 \\
4,40 \\
0.18 \\
0,16 \\
0.44\end{array}$ & $\begin{array}{r}66,50 \\
0,54 \\
15,40 \\
2,00 \\
1,80 \\
0,05 \\
1,30 \\
3,00 \\
3,90 \\
4,20 \\
0,19 \\
0,13 \\
0,53\end{array}$ \\
\hline \multirow{10}{*}{$\begin{array}{l}\text { TOTAL } \\
\mathrm{H}_{2} \mathrm{O}+ \\
\mathrm{H}_{2} \mathrm{O}- \\
\mathrm{S} \\
\mathbf{C} \\
\mathrm{Cl} \\
\mathrm{Ba} \\
\mathrm{Rb} \\
\mathrm{Sr} \\
\mathbf{2 r} \\
\mathrm{Nb} \\
\mathrm{Ni} \\
\mathrm{Y} \\
\mathrm{V} \\
\mathrm{Cr} \\
\end{array}$} & 99,57 & 99,60 & 99,57 & 99.55 & 99.54 & 99.67 & 99,43 & 99,54 & 99,48 & 99,68 & 99,43 & 99,46 & 99,43 & 99,60 & 99,60 & 99,73 & 99,88 & 99,70 & 99,66 & 99,54 \\
\hline & 0.35 & 0.89 & 0.54 & 0,57 & 0.54 & 0,51 & 1,08 & 0,61 & 0,57 & 0.51 & 0,95 & 0,81 & 0.73 & 0,44 & 0.57 & 0,52 & 0,40 & 0,39 & 0,32 & 0,24 \\
\hline & 0.12 & 0,30 & 0,17 & 0,17 & 0,12 & 0,20 & 0.13 & 0,47 & 0.21 & 0,29 & 0,25 & 0,40 & 0.24 & 0,09 & 0.20 & 0,17 & 0,12 & 0,22 & 0.19 & 0,13 \\
\hline & $\begin{array}{r}0,071 \\
120\end{array}$ & $\begin{array}{r}<0,005 \\
64\end{array}$ & $\begin{array}{r}0.012 \\
73\end{array}$ & $\begin{array}{r}0.28 \\
47\end{array}$ & $\begin{array}{r}40,005 \\
310\end{array}$ & $\begin{array}{r}0,0099 \\
250\end{array}$ & $\begin{array}{r}0,053 \\
390\end{array}$ & $\begin{array}{r}0,021 \\
150\end{array}$ & $\begin{array}{r}0,032 \\
180\end{array}$ & $\begin{array}{r}<0,005 \\
110\end{array}$ & $\begin{array}{r}0,006 \\
310\end{array}$ & $\begin{array}{r}8.005 \\
380\end{array}$ & $\begin{array}{r}0,007 \\
280\end{array}$ & $\begin{array}{r}0.01 \\
79\end{array}$ & $\begin{array}{r}0,005 \\
85\end{array}$ & $\frac{<0,005}{85}$ & $\begin{array}{r}<0,005 \\
34\end{array}$ & $<0,005$ & $\begin{array}{r}40,005 \\
99\end{array}$ & $\begin{array}{r}40,005 \\
160\end{array}$ \\
\hline & $\begin{array}{r}1630 \\
120\end{array}$ & $\begin{array}{l}390 \\
140\end{array}$ & $\begin{array}{r}730 \\
78\end{array}$ & $\begin{array}{r}410 \\
93\end{array}$ & $\begin{array}{r}1460 \\
89\end{array}$ & $\begin{array}{r}1330 \\
99\end{array}$ & $\begin{array}{r}1310 \\
57\end{array}$ & $\begin{array}{r}1430 \\
110\end{array}$ & 1470 & $\begin{array}{r}1370 \\
130\end{array}$ & $\begin{array}{r}1470 \\
96\end{array}$ & $\begin{array}{r}1720 \\
100\end{array}$ & 1740 & 1200 & 1110 & 940 & 930 & 1000 & 1420 & 1160 \\
\hline & 1200 & 360 & 1590 & 1460 & 870 & 800 & 1040 & 850 & 820 & $\begin{array}{l}130 \\
920\end{array}$ & 970 & $\begin{array}{l}100 \\
920\end{array}$ & $\begin{array}{r}90 \\
850\end{array}$ & $\begin{array}{l}130 \\
710\end{array}$ & $\begin{array}{l}120 \\
380\end{array}$ & $\begin{array}{l}140 \\
630\end{array}$ & $\begin{array}{l}110 \\
820\end{array}$ & $\begin{array}{r}90 \\
820\end{array}$ & $\begin{array}{l}130 \\
860\end{array}$ & $\begin{array}{l}120 \\
850\end{array}$ \\
\hline & $\begin{array}{r}330 \\
18\end{array}$ & $\begin{array}{r}130 \\
11\end{array}$ & 86 & $\begin{array}{r}120 \\
8\end{array}$ & $\begin{array}{r}260 \\
10\end{array}$ & $\begin{array}{r}250 \\
10\end{array}$ & $\begin{array}{r}130 \\
13\end{array}$ & $\begin{array}{r}270 \\
17\end{array}$ & $\begin{array}{r}290 \\
20\end{array}$ & $\begin{array}{r}250 \\
15\end{array}$ & $\begin{array}{r}240 \\
19\end{array}$ & $\begin{array}{r}290 \\
13\end{array}$ & $\begin{array}{r}300 \\
16\end{array}$ & $\begin{array}{r}190 \\
12\end{array}$ & $\begin{array}{r}200 \\
10\end{array}$ & $\begin{array}{r}180 \\
88\end{array}$ & $\begin{array}{r}160 \\
8\end{array}$ & $\begin{array}{l}170 \\
48\end{array}$ & $\begin{array}{r}250 \\
<8\end{array}$ & $\begin{array}{r}240 \\
11\end{array}$ \\
\hline & $\begin{array}{r}20 \\
29\end{array}$ & $\begin{array}{l}59 \\
33\end{array}$ & $\begin{array}{l}20 \\
10\end{array}$ & $\begin{array}{r}<0 \\
14\end{array}$ & $\begin{array}{l}38 \\
24\end{array}$ & $\begin{array}{l}35 \\
23\end{array}$ & 35 & $\begin{array}{l}20 \\
26\end{array}$ & $\frac{20}{26}$ & $\frac{20}{30}$ & $\begin{array}{l}40 \\
31\end{array}$ & $\begin{array}{l}36 \\
33\end{array}$ & 31 & 20 & ${ }_{n}^{16}$ & $<20$ & 20 & $<0$ & 20 & 80 \\
\hline & 65 & 130 & 43 & 53 & 100 & 87 & 190 & 64 & 64 & 36 & 150 & 150 & 140 & $\begin{array}{l}28 \\
43\end{array}$ & 39 & 54 & is & 24 & 42 & 4 \\
\hline & $<20$ & 210 & 21 & 23 & 81 & 68 & 96 & $<0$ & $<20$ & $<0$ & 300 & 92 & 98 & 20 & 37 & $<0$ & $<20$ & $<20$ & 24 & $\underline{n}$ \\
\hline \multirow[b]{2}{*}{ 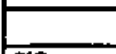 } & & & & & & & & & & & & & & & & & & & & \\
\hline & TC-2 & TC-14 & TC-15 & TC-16 & S-1 & 5.5 & S.15 & PT.1 & B-2 & L.S & L-16 & MA-1 & VA.1 & VA-2 & SgI-A & $S_{B}^{2-G}$ & Co-2 & $\infty 0-5$ & $\infty-7$ & CV-1 \\
\hline \multirow{22}{*}{ 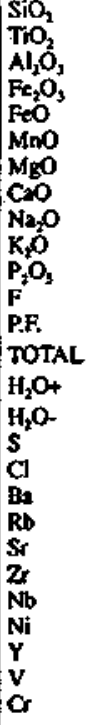 } & & $\begin{array}{r}60,000 \\
082\end{array}$ & $\begin{array}{r}67.70 \\
0.59\end{array}$ & $\begin{array}{r}67.50 \\
0.60\end{array}$ & $\begin{array}{r}70,30 \\
0.37\end{array}$ & $\begin{array}{r}70,20 \\
0.34\end{array}$ & 65,90 & $\begin{array}{r}61,30 \\
0,72\end{array}$ & $\begin{array}{r}70,20 \\
0.38\end{array}$ & 7120 & 71,20 & $\begin{array}{r}72,20 \\
0.06\end{array}$ & 71,90 & 68.90 & $\begin{array}{r}71,30 \\
325\end{array}$ & 73,30 & 73,60 & $\begin{array}{r}73,30 \\
0.17\end{array}$ & 73,50 & 76,00 \\
\hline & $\begin{array}{r}0.64 \\
15,10\end{array}$ & $\begin{array}{r}0,82 \\
15,70\end{array}$ & $\begin{array}{r}0,59 \\
14,70\end{array}$ & $\begin{array}{r}0,60 \\
14,50\end{array}$ & $\begin{array}{r}0,37 \\
14,60\end{array}$ & $\begin{array}{r}0,34 \\
14,30\end{array}$ & $\begin{array}{r}0,59 \\
14,90\end{array}$ & $\begin{array}{r}0,72 \\
16,50\end{array}$ & $\begin{array}{r}0,38 \\
14,40\end{array}$ & $\begin{array}{r}0,30 \\
14,70\end{array}$ & $\begin{array}{r}0,31 \\
14,70\end{array}$ & $\begin{array}{r}0,06 \\
14,90\end{array}$ & $\begin{array}{r}0.28 \\
14,40\end{array}$ & $\begin{array}{r}0,41 \\
15,00\end{array}$ & $\begin{array}{r}0,35 \\
13,90\end{array}$ & $\begin{array}{r}0,18 \\
13,70\end{array}$ & $\begin{array}{r}0,19 \\
13,60\end{array}$ & $\begin{array}{r}0,17 \\
13,30\end{array}$ & $\begin{array}{r}0,11 \\
13,60\end{array}$ & $\begin{array}{r}0,11 \\
12,30\end{array}$ \\
\hline & 2,00 & 3,00 & 1.20 & 1.80 & 0.96 & 1.70 & $3, \infty$ & 270 & 1,20 & 0,26 & 0,87 & 0,36 & 1,20 & 2.00 & 1,10 & 0.67 & 0.58 & 0.81 & 0,77 & 0.62 \\
\hline & $\begin{array}{l}1,70 \\
0,05\end{array}$ & $\begin{array}{l}3,50 \\
0.10\end{array}$ & $\begin{array}{l}2.00 \\
0,05\end{array}$ & $\begin{array}{l}1.70 \\
0.05\end{array}$ & $\begin{array}{l}1.30 \\
0.03\end{array}$ & $\begin{array}{l}0.84 \\
0.03\end{array}$ & $\begin{array}{l}1.10 \\
0.07\end{array}$ & $\begin{array}{l}3,10 \\
0.09\end{array}$ & $\begin{array}{l}1,40 \\
0,05\end{array}$ & 1,30 & 0,84 & $\begin{array}{l}0.42 \\
0.01\end{array}$ & $\begin{array}{l}0.70 \\
0.04\end{array}$ & $\begin{array}{l}0,98 \\
0,04\end{array}$ & $\begin{array}{l}1.50 \\
0.06\end{array}$ & 0.84 & $\begin{array}{l}1.10 \\
0.05\end{array}$ & 0.98 & 0,84 & 0.70 \\
\hline & 1,40 & 2.70 & 1,40 & 1.40 & 0,76 & 0,87 & 1,50 & 1.90 & 1.00 & 0,54 & 0.55 & 0,22 & 0,43 & 0888 & 0,34 & 0,24 & 0,20 & 0,23 & 0,18 & 0,12 \\
\hline & 280 & 4,80 & 270 & 2,90 & 1,80 & 1,80 & 3,00 & 4,60 & 2.40 & 1.70 & 1.80 & 1.20 & 1,40 & 2,10 & 1,20 & 1,10 & 1,00 & 1,20 & 0.87 & 0.55 \\
\hline & $\begin{array}{l}4,00 \\
430\end{array}$ & 3,60 & $\begin{array}{l}3,70 \\
400\end{array}$ & $\begin{array}{r}3.70 \\
460\end{array}$ & 4.60 & 4,80 & 3.70 & 3,70 & 3.50 & 4.10 & 4,00 & 3,50 & 4,10 & 3,60 & $\begin{array}{l}3,50 \\
500\end{array}$ & 3,30 & $\begin{array}{l}3,30 \\
540\end{array}$ & 3,40 & 3.50 & 3,30 \\
\hline & $\begin{array}{l}4.30 \\
0.21\end{array}$ & $\begin{array}{l}4.10 \\
0.30\end{array}$ & $\begin{array}{l}4,90 \\
0,19\end{array}$ & $\begin{array}{l}4,60 \\
0,20\end{array}$ & $\begin{array}{l}4,20 \\
0,16\end{array}$ & $\begin{array}{l}4.00 \\
0.13\end{array}$ & $\begin{array}{l}4.70 \\
0.23\end{array}$ & $\begin{array}{l}3,90 \\
0,28\end{array}$ & $\begin{array}{l}4,30 \\
0.11\end{array}$ & $\begin{array}{l}4,90 \\
0.08\end{array}$ & $\begin{array}{l}4,90 \\
0,09\end{array}$ & $\begin{array}{r}6.50 \\
<0.05\end{array}$ & $\begin{array}{l}4,60 \\
0,07\end{array}$ & $\begin{array}{l}5,00 \\
0.13\end{array}$ & $\begin{array}{l}5,90 \\
0.10\end{array}$ & $\begin{array}{r}5.80 \\
4.05\end{array}$ & $\begin{array}{r}5,40 \\
-0,05\end{array}$ & $\begin{array}{r}5,40 \\
40,05\end{array}$ & $\begin{array}{r}5,50 \\
5,05\end{array}$ & $\begin{array}{r}5,30 \\
0.05\end{array}$ \\
\hline & 0.11 & 0,12 & 0.12 & 0.10 & 0,11 & 0.06 & 0.10 & 0,11 & 0.11 & 0,17 & 0.13 & 0,034 & 0,13 & 0.099 & 0.13 & 0,13 & 0,19 & 0,20 & 0,25 & 0,20 \\
\hline & 0,48 & $0, \pi$ & 0,52 & 0,64 & 0.43 & 0,44 & 0.85 & 0,68 & 0.71 & 0.47 & 0.38 & 0.52 & 0.56 & 0.60 & 0.43 & 0.56 & 0,77 & & 0,76 & 0,75 \\
\hline & 99,59 & 99,51 & 99,77 & 99,69 & 99,62 & 99,55 & 99,64 & 99,58 & 99.76 & 99,74 & 99,80 & 99,97 & 99,81 & 99,74 & 99,81 & 99,91 & 100,03 & 99,99 & 99.97 & 100,03 \\
\hline & 0,40 & 0,53 & 0,38 & 0.54 & 0.34 & 0.32 & 0.55 & 0,64 & 0,45 & 0,19 & 0.12 & 0.19 & 0,42 & 0,37 & 0,37 & 0,38 & 0,26 & 0,38 & 0,59 & 0,40 \\
\hline & 0,14 & 0.20 & 0.18 & 0,14 & 0,17 & 0,18 & 0,12 & 0.12 & 0,10 & 0.12 & 0.24 & 0.13 & 0.20 & 0.20 & 0,19 & 0,14 & 0.18 & 0,17 & 0,10 & 0,28 \\
\hline & $<0.005$ & 0.014 & $<0,005$ & $<0,005$ & 0,006 & 0,006 & $<0,005$ & 0,012 & $<0,005$ & 0,014 & $\$ 0,005$ & 40,005 & $<0,005$ & $<0,005$ & 80,005 & $<0,005$ & $<0,0$ & $<0,005$ & $\infty 0,005$ & $<0,005$ \\
\hline & $\begin{array}{r}65 \\
1630\end{array}$ & 130 & 140 & 89 & 21 & 25 & 200 & 65 & 62 & 50 & 40 & & 75 & 92 & 98 & 95 & 110 & & 92 & 140 \\
\hline & 1630 & 1550 & 1640 & 1540 & 1520 & 1290 & 1330 & 1630 & 950 & 1290 & 1460 & 920 & 1040 & 1420 & 770 & 400 & 370 & 360 & 260 & 76 \\
\hline & $\begin{array}{r}120 \\
1030\end{array}$ & & 120 & 100 & 70 & 71 & 130 & 91 & $\mathbf{1 4 0}$ & 180 & 160 & 190 & 160 & 140 & 310 & 370 & 370 & 370 & 470 & 300 \\
\hline & $\begin{array}{r}1030 \\
290\end{array}$ & $\begin{array}{l}900 \\
260\end{array}$ & 860 & 940 & 1120 & 1130 & 810 & 720 & 500 & 910 & 940 & 550 & 660 & 1000 & 170 & 150 & 330 & 120 & 110 & 32 \\
\hline & $\begin{array}{r}290 \\
14\end{array}$ & $\begin{array}{r}260 \\
16\end{array}$ & 240 & $\begin{array}{r}270 \\
9\end{array}$ & $\stackrel{190}{8}$ & $\stackrel{200}{8}$ & $\begin{array}{r}220 \\
14\end{array}$ & $\begin{array}{r}250 \\
11\end{array}$ & $\begin{array}{r}190 \\
8\end{array}$ & $\begin{array}{r}210 \\
8\end{array}$ & $\begin{array}{r}180 \\
88\end{array}$ & $\begin{array}{l}91 \\
8\end{array}$ & $\begin{array}{r}220 \\
25\end{array}$ & $\begin{array}{r}210 \\
12\end{array}$ & $\begin{array}{l}400 \\
27\end{array}$ & $\begin{array}{r}210 \\
24\end{array}$ & $\begin{array}{r}200 \\
28\end{array}$ & $\begin{array}{r}200 \\
17\end{array}$ & $\begin{array}{r}170 \\
37\end{array}$ & $\begin{array}{r}200 \\
35\end{array}$ \\
\hline & 23 & 20 & 20 & 20 & $<0$ & $<0$ & 20 & $\infty$ & $<20$ & $<0$ & $<0$ & $<0$ & 20 & $<0$ & 20 & $\infty$ & $<20$ & $<20$ & 20 & 80 \\
\hline & $\begin{array}{l}29 \\
54\end{array}$ & $\begin{array}{r}27 \\
110\end{array}$ & $\begin{array}{l}76 \\
45\end{array}$ & $\begin{array}{l}63 \\
47\end{array}$ & $\begin{array}{r}170 \\
28\end{array}$ & 14 & $\begin{array}{l}23 \\
56\end{array}$ & $\begin{array}{l}29 \\
\mathbf{8 2}\end{array}$ & $\begin{array}{l}30 \\
37\end{array}$ & 11 & 10 & ${ }_{-10}^{11}$ & 150 & $\begin{array}{r}230 \\
30\end{array}$ & 84 & n & $\begin{array}{r}87 \\
<10\end{array}$ & 61 & 350 & 51 \\
\hline & 34 & 41 & 39 & 36 & $<20$ & $<20$ & 28 & 23 & 29 & $<20$ & $<0$ & 20 & $<20$ & $<20$ & $<0$ & $<20$ & $<20$ & $<20$ & 80 & $\infty$ \\
\hline
\end{tabular}


Tabela 3 - Dados de elementos terras raras. Veja Tab. 1 para relacionar o litotipo analisado Table 3 - Rare earth element data. See Tab. 1 to relate sample and lithotype

\begin{tabular}{|c|c|c|c|c|c|c|c|c|c|c|}
\hline AMOSTRAS & MP-1 & MN-1 & GD1-A & GD2-C & ET-51 & ET-48 & TC-15 & s-15 & L-5 & $\mathrm{Co-7}$ \\
\hline $\mathbf{L a}$ & 147,000 & 15,530 & 71,740 & 57,170 & 83,810 & 59,650 & 65,420 & 55,390 & 30,030 & 66,370 \\
\hline $\mathrm{Ce}$ & 323,800 & 35,970 & 134,600 & $\$ 17,400$ & 197,200 & 125,700 & 132,600 & 118,400 & 76,040 & 128,100 \\
\hline Nd & 150,200 & 17,420 & 61,050 & 47,280 & 87,630 & 48,880 & 50,520 & 46,660 & 28,290 & 52,580 \\
\hline $\mathrm{Sm}$ & 23,900 & 2,924 & 10,250 & 7,710 & 14,870 & 7,548 & 7,767 & 7,655 & 4,066 & 11,130 \\
\hline $\mathbf{E u}$ & 4,516 & 0,744 & 1,969 & 1,409 & 2,753 & 1,360 & 1,434 & 1,435 & 0,741 & 0,687 \\
\hline Gd & 13,610 & 1,694 & 6,413 & 4,743 & 9,017 & 4,165 & 5,021 & 4,679 & 2,036 & 9,077 \\
\hline Dy & 9,889 & 1,281 & 4,800 & 3,546 & 6,594 & 2,554 & 3.675 & 3,259 & 1,144 & 14,860 \\
\hline Ho & 1,832 & 0,249 & 0,985 & 0,683 & 1,323 & 0.472 & 0.815 & 0,623 & 0,215 & 3,960 \\
\hline $\mathrm{Ex}$ & 4,200 & 0,629 & 2,777 & 1,709 & 3,581 & 1,084 & 2,594 & 1,534 & 0,510 & 15,610 \\
\hline $\mathbf{Y b}$ & 2,805 & 0,597 & 1,693 & 1,177 & 2,049 & 0,781 & 1.712 & 1,177 & 0,361 & 19,400 \\
\hline Lu & 0,309 & 0,089 & 0,323 & 0,145 & 0,353 & 0,108 & 0.263 & 0,165 & 0,063 & 2,809 \\
\hline
\end{tabular}

Tabela 4 - Dados comparativos de análises químicas (chamadas de PT-2 e CV-2), obtidas juntamente com as da Tab. 2, e previamente disponiveis (NF10 e NF15)

Table 4 - Comparative data between samples (named PT-2 and CV-2) analysed together with those from Tab. 2, and previously available data (NF 10 and NFI5)

\begin{tabular}{|c|c|c|c|c|c|c|}
\hline & NFIO LCands & PT-2 GEOLAB & DIFERENCA" & NF15 LComall & CV-2 GEOLAI & DIFERENÇA \\
\hline $\mathrm{SiO}_{2} \%$ & 52,00 & 50,90 & $-2,11$ & 72,60 & 72,40 & $-0,28$ \\
\hline $\mathrm{TiO}_{2} \%$ & 1,62 & 1,70 & 4,94 & 0,29 & 0,29 & - \\
\hline $\mathrm{Al}_{2} \mathrm{O}_{3} \%$ & 15,40 & 16,00 & 3,90 & 13,40 & 13,80 & 2,9 \\
\hline $\mathrm{Fe}_{2} \mathrm{O}_{3} \%$ & 10,5 & $4,7 \dot{0}$ & - & 0,73 & 0,85 & 16,4 \\
\hline FeO\% & - & 5,80 & - & 1,99 & 2,00 & 0,50 \\
\hline $\mathrm{MnO} \%$ & 0,17 & 0,18 & 5,88 & 0,05 & 0,05 & - \\
\hline $\mathrm{MgO} \%$ & 6,20 & 5,80 & $-6,45$ & 0.78 & 0,86 & 10,26 \\
\hline $\mathrm{CaO} \%$ & 8,06 & 8,40 & 4,22 & 2,01 & 2,00 & $-0,50$ \\
\hline $\mathrm{Na}_{2} \mathrm{O} \%$ & 3,10 & 3,30 & 6,45 & 3,87 & 4,20 & 8,53 \\
\hline $\mathrm{K}_{2} \mathrm{O} \%$ & 1,42 & 1,60 & 12,68 & 2,55 & 2,80 & 9,80 \\
\hline $\mathrm{P}_{2} \mathrm{O}_{5} \%$ & 0,45 & 0,47 & 4,44 & 0,10 & 0,05 & $-50,00$ \\
\hline $\mathrm{Ba}(\mathrm{ppm})$ & 437 & 370 & $-15,33$ & 728 & 700 & $-3,85$ \\
\hline Rb" & 34 & 30 & $-11,76$ & 45 & 52 & 15,55 \\
\hline$S r^{*}$ & 466 & 440 & $-5,58$ & 199 & 250 & 25,63 \\
\hline $\mathrm{Zr}^{* 4}$ & 198 & 200 & 1,01 & 180 & 220 & 22,22 \\
\hline $\mathbf{N b}^{*}$ & 16 & 14 & $-12,50$ & 4 & $<8$ & - \\
\hline $\mathrm{Ni}^{* *}$ & 56 & 63 & 12,50 & 3 & $<20$ & - \\
\hline $\mathrm{Cr}^{*}$ & 134 & 160 & 19,40 & 1 & $<20$ & - \\
\hline $\mathrm{v}^{\prime \prime}$ & 178 & 190 & 6,74 & 22 & 26 & 18,18 \\
\hline
\end{tabular}

cálcica, o que normalmente ocorre com seqüências cálcioalcalinas de alto-K ou shoshoníticas.

As rochas aqui analisadas são predominantemente subalcalinas (Fig. 6), com exceção de um dos enclaves dos augen gnaisses (MP-1), mais alcalino principalmente devido ao seu teor mais elevado de sódio. Os enclaves mais básicos caem próximos ao limite entre os campos alcalino e subalcalino, como costuma acontecer com as rochas básicas (e.g., dioritos potássicos) das suítes cálcio-alcalinas de alto$\mathrm{K}$ a shoshoníticas. $\mathrm{O}$ caráter cálcio-alcalino de alto-K a shoshonítico das rochas em investigação, com exclusão dos augen gnaisses e de um de seus enclaves (MP-14), pode ser observado na Figura 7 (os granitos pós-tectônicos têm teores de $\mathrm{K}_{2} \mathrm{O}$ acima de 5\%).

As amostras estudadas são metaluminosas (Fig. 8), com algumas poucas amostras dos granitos pós-tectônicos sendo levemente peraluminosas, o que é normal para biotita granitos e granitos do tipo-I bem diferenciados.

No diagrama R1-R2 de De La Roche et al. (1980), a classificação dos litotipos seria aproximadamente equivalente àquela descrita acima para o diagrama P-Q, com uma melhor distinção entre os "hornblenda-biotita granitóides" e os "leucogranitóides". Neste diagrama (Fig. 9), com a discriminação tectônica sugerida por Batchelor \& Bowden (1985), a tendência da seqüência Três Córregos cai no campo dos granitóides de soerguimento pós-colisional do tipo Caledoniano, onde também plotam os granitóides de arcos magmáticos maduros de margem continental, como algumas suítes andinas.

As relações $\mathrm{Sr}-\mathrm{Ba}-\mathrm{Rb}$ distinguem claramente os granitos pós-tectônicos, com características de granitos fortemente diferenciados, das demais rochas estudadas, em virtude do 


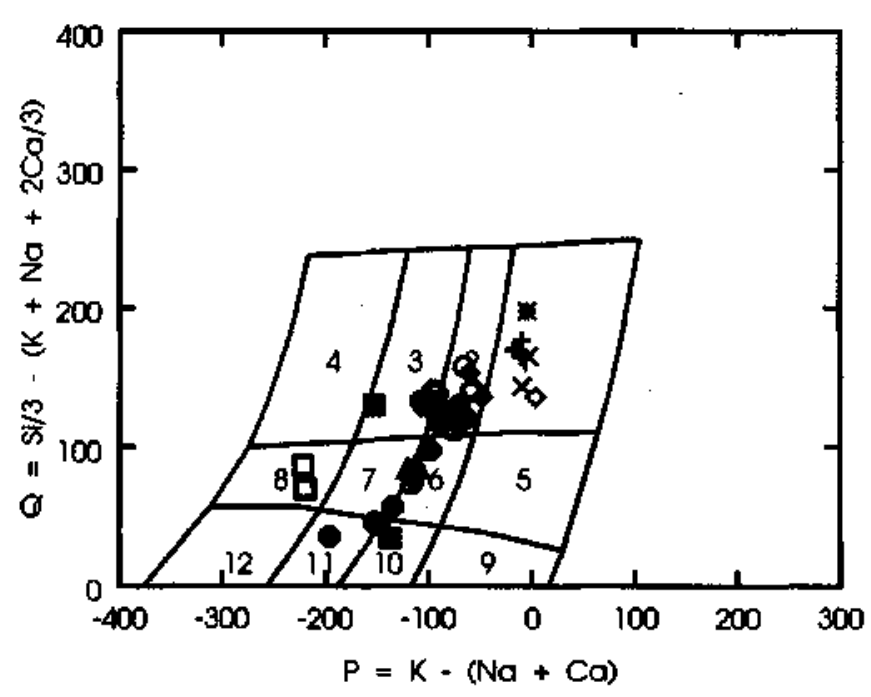

Figura 5 - Q-P diagrama (Debon \& Le Fort 1983) para as amostras analisadas. Mesma simbologia da Fig. 3. Campos: 1 - granito; 2 - adamelito; 3 - granodiorito; 4 - tonalito; 5 - quartzo sienito; 6 - quartzo monzonito; 7 - quartzo monzodiorito; 8 - quartzo diorito; 9 - sienito; 10 - monzonito; 11 - monzogabro; 12 - gabro

Figure 5 - Q-P diagram (Debon \& Le Fort 1983) for the analysed samples. Symbols as in Fig. 3. Fields: 1 - granite; 2 - adamellite; 3 - granodiorite; 4 - tonalite; 5 - quartz syenite; 6 - quartz monzonite; 7 - quartz monzodiorite; 8 - quartz diorite; 9 - syenite; 10 - monzonite; 11 - monzogabbro; 12 gabbro

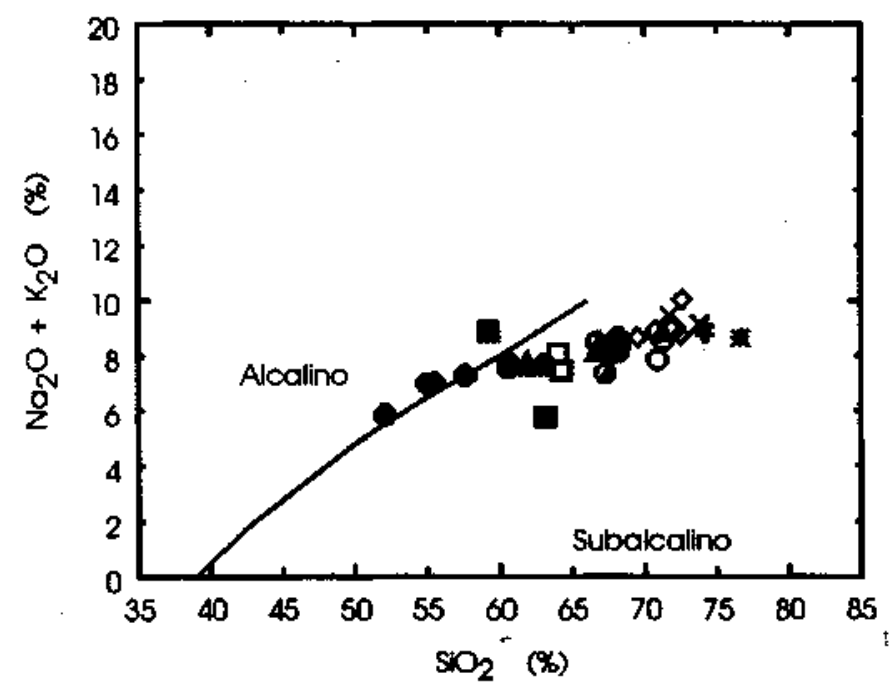

Figura 6 - Diagrama silica versus álcalis totais (Irvine \& Baragar 1971), com os campos alcalino e subalcalino, para as amostras analisadas. Mesma simbologia da Fig. 3 Figure 6 - TAS diagram (Irvine \& Baragar 1971) with the alkaline and sub-alkaline fields, for the analysed samples. Symbols as in Fig. 3

relativo enriquecimento em Rb (El Bouseily \& El Sokkary 1975).

No diagrama discriminante tectônico $\mathrm{Y}+\mathrm{Nb}$ versus $\mathrm{Rb}$ (Fig. 10), de Pearce et al. (1984), a seqüência Três Córregos distribui-se na parte superior direita do campo dos granitos de arcos magmáticos pré-colisionais, onde também plotam os granitos tipo Caledoniano, enquanto os granitos póstectônicos (e algumas amostras de granitóidès porfiróides e veios graníticos, em virtude de teores elevados de Y) caem no campo dos granitos intra-placa.

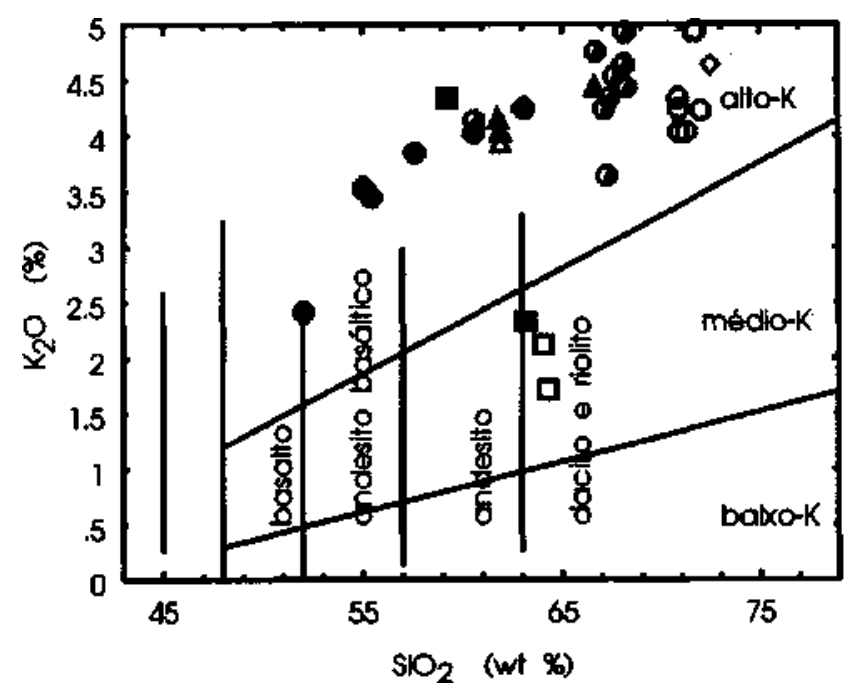

Figura 7 - Diagrama silica versus $\mathrm{K}_{2} \mathrm{O}$ (Lê Maitre 1989) para as amostras analisadas. Mesma simbologia da Fig. 3 Figure 7 - Silica- $\mathrm{K}_{2} \mathrm{O}$ diagram (Le Maitre 1989) for the analysed samples. Symbols as in Fig. 3

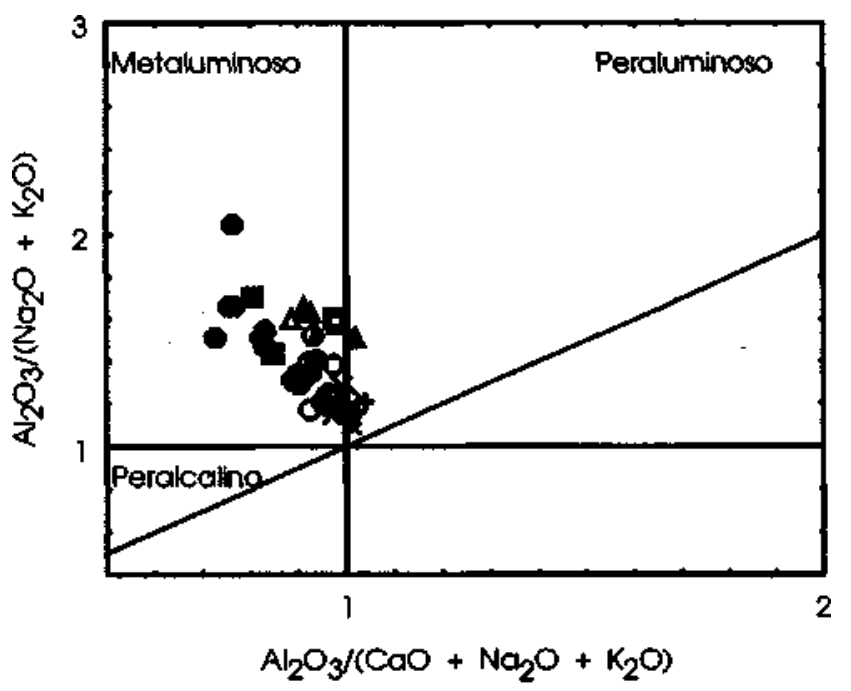

Figura 8 - indices de Shand no diagrama de Maniar \& Piccoli (1989) para as amostras analisadas. Mesma simbologia da Fig. 3

Figure 8 - Shand's indices in the Maniar \& Piccoli (1989) diagram for the analysed samples. Symbols as in Fig. 3

A distribuição de elementos Terras Raras (TR) em enclaves dos granitóides orientados (GDI-A e GD2-C) e em enclave do granitóide Barra do Chapéu (ET-51) é muito semelhante, com padrões bem enriquecidos e fracionados, com leve anomalia negativa de Eu (Fig. 11). Uma amostra de augen gnaisse (MN-1) é bem menos enriquecida e fracionada e não apresenta anomalia de Eu, com um padrão mais "andesítico", enquanto um enclave em augen gnaisses (MP-1) tem padrão muito semelhante aos dos enclaves Três Córregos, sendo ainda ligeiramente mais enriquecido.

Os padrões de distribuição de Terras Raras (REE) de granitóidès Três Córregos com cerca de $67 \%$ de silica (ET-48, TC-15 e S-15), são enriquecidos em Terras Raras leves (LREE), apresentam leve anomalia negativa de Eu e Terras Raras pesadas (HREE) algo variáveis (Fig. 12), sendo comparáveis aos padrões dos enclaves discutidos acima, com exceção do fracionamento variável de HREE. 


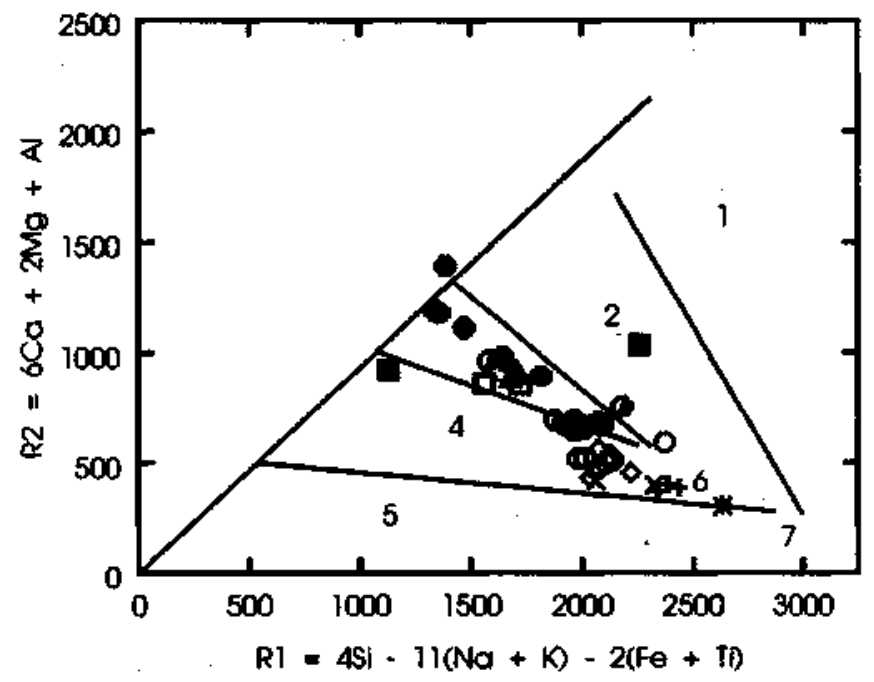

Figura 9 - Diagrama R1-R2 (De La Roche et al. 1980), com os campos de discriminação tectônica de granitóides (Batchelor \& Bowden 1985), para as amostras analisadas. Mesma simbologia da Fig. 3. Campos: 1 -fracionados do Manto; 2 - pré-colisionais; 3 - soerguimento pós-colisional; 4 - tardi-orogênico; 5 - anorogênico; 6 - sin-colisional; 7 pós-orogênico

Figure 9 - R1-R2 diagram (De La Roche et al. 1980) with the tectonic discrimination for granitoids (Batchelor \& Bowden 1985) for the analysed samples. Symbols as in Fig. 3. Fields: 1- Mantle fractionates; 2 - pre-plate collision; 3 - post-collision uplift; 4 - late-orogenic; 5 - anorogenic; 6 syn-collision; 7 - post-orogenic

Uma amostra do granito Lajeado (L-5) é menos enriquecida em REE, quase sem anomalia de Eu. A única amostra de granito pós-tectônico analisada para TR (CO-7) apresenta enriquecimento de LREE e HREE e forte anomalia negativa de Eu, com um padrão "gaivota" típico de granitos anorogênicos de fusão crustal. Cabe salientar que esta amostra é a que apresenta o teor mais elevado de Y (350 ppm), que tem um comportamento geoquímíco idêntico ao das TRP, e é possível que outras amostras da suíte pós-tectônica (com teores de Y abaixo de 100 ppm) não sejam tão enriquecidas em HREE.

Os diagramas expandidos de distribuição de elementos incompatíveis ("aranhogramas") normalizados por NMORB (Pearce 1983), para os enclaves nos granitóides Três Córregos (Fig. 13), apresentam um padrão típico de componentes de zona de subducção (SZC) com fracionámento seqüencial de LILE (elementos litófilos de raio iônico grande), LREE, HREE e HFSE (elementos de alto campo de força), com enriquecimento pronunciado em LILE e anomalias negativas de $\mathrm{Nb}, \mathrm{P}$ e Ti. Cabe salientar que o augen gnaisse (MN-1) tem padrão distinto, com teores mais baixos de todos os elementos incompatíveis, menos $\mathrm{Sr}$, e que seu enclave (MP-1) tem padrão parecido com os dos enclaves nos granitóides Três Córregos, sendo levemente mais enriquecido em REE.

Os "aranhogramas" (Fig. 14) para os granitóides Três Córregos, com teores de silica da ordem de 67\% (ET-48, TC-15 e S-15) são muito semelhantes aos apresentados pelos enclaves, também com nítidos SZC, com a exceção do teor mais elevado de Y na amostra TC-15. A amostra do granito Lajeado (L-5), mais silicosa, apresenta o mesmo tipo geral de distribuição de elementos incompatíveis, com fracionámento algo maior, em virtude de teores um pouco mais baixos de $\mathrm{Ce}, \mathrm{P}, \mathrm{Sm}, \mathrm{Ti}, \mathrm{Y}$ e $\mathrm{Yb}$. A amostra do granito Correias (CO-7) tem padrão muito distinto, com empobrecimento de $\mathrm{Ba}$ e teores mais altos de $\mathrm{Y}$ e HREE, sugestivo de granitos intraplaca (Pearce et al. 1984).

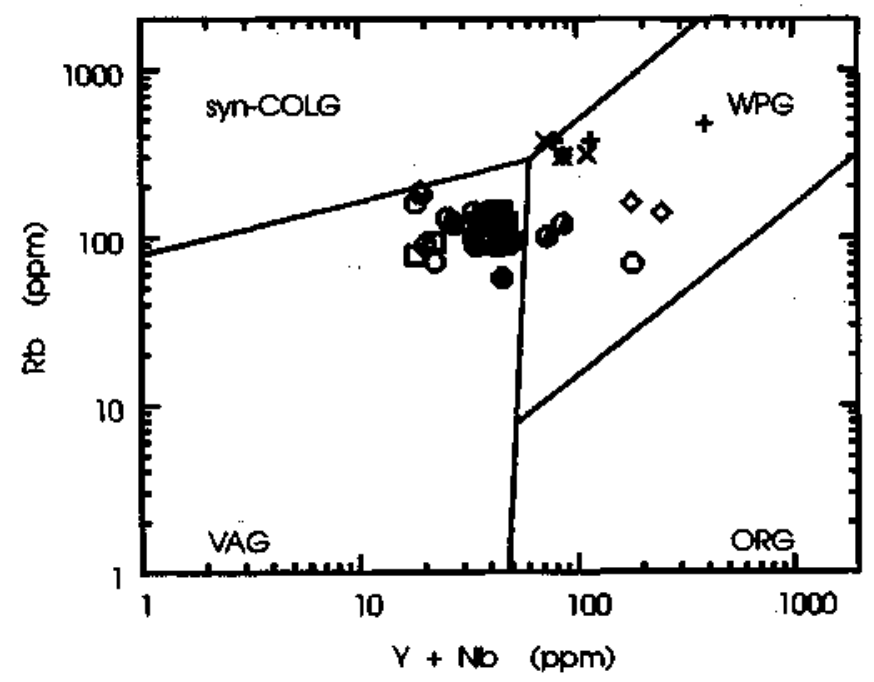

Figura 10 - Diagrama $R b-(Y+N b)$ com a discriminação tectônica de granitóides (Pearce et al. 1984) para as amostras analisadas. Mesma simbologia da Fig. 3. Campos: synCOLG - granitos sin-colisionais; WPG - granitos intraplaca; VAG- granitos de arco vulcânico; ORG -granitos de cadeia ocê̂nica

Figure $10-\mathrm{Rb}-(\mathrm{Y}+\mathrm{Nb})$ discrimination diagram (Pearce et al. 1984) for the analysed samples. Symbols as in Fig. 3. Fields: syn-COLG - syncollisional granites; WPG - within-plate granites; VAG - volcanic arc granites; ORG - ocean ridge granites

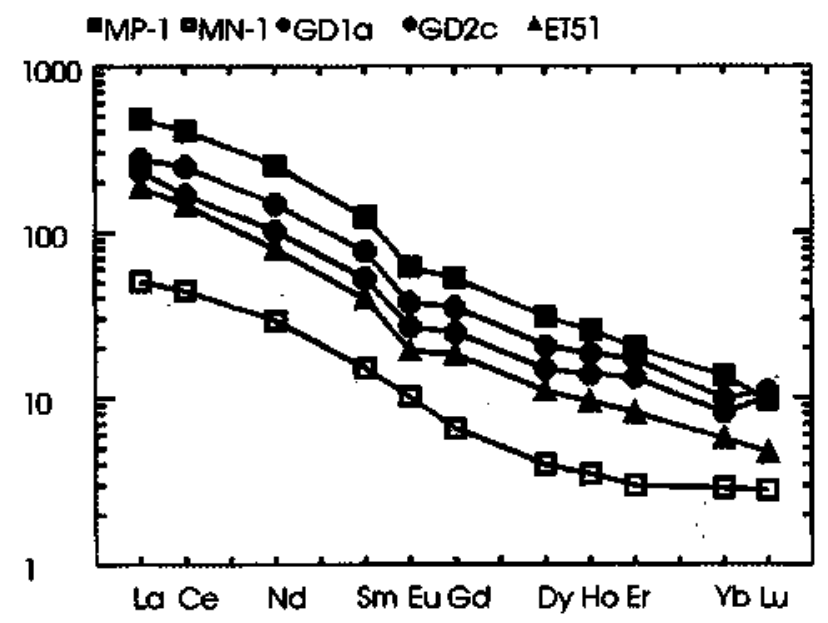

Figura 11 - Diagrama de distribuição de elementos Terras Raras, normalizados pelo condrito de Evensen et al. (1978) multiplicado por 1,27, para enclaves no granitóide Três Córregos (ET-51), nos granitóides orientados (GD-la e $G D-2 c)$ e no augen gnaisse (MP-1) e para augen gnaisse $(M N-1)$

Figure 11 - REE distribution patterns, normalised by Evensen et al. (1978) chondrite values multiplied by 1.27, for enclaves in Três Córregos granitoid (ET-S1), in foliated granitoids (GD-la and GD-2c) and in augen gneiss (MP-1) and for augen gneiss (MN-1)

CONCLUSÕES E INFERENCES DE ORDEM TECTÔNICA No diagrama QAP (Fig. 3) os conjuntos das amostras do Complexo Granítico Três Córregos e dos enclaves apresentam nítida afinidade com o campo da série cálcio-alcalina de médio a alto-K (Lameyre \& Bowden 1982). As amostras dos granitos pós-tectônicos situam-se no campo de granitóides formados por fusão crustal. 


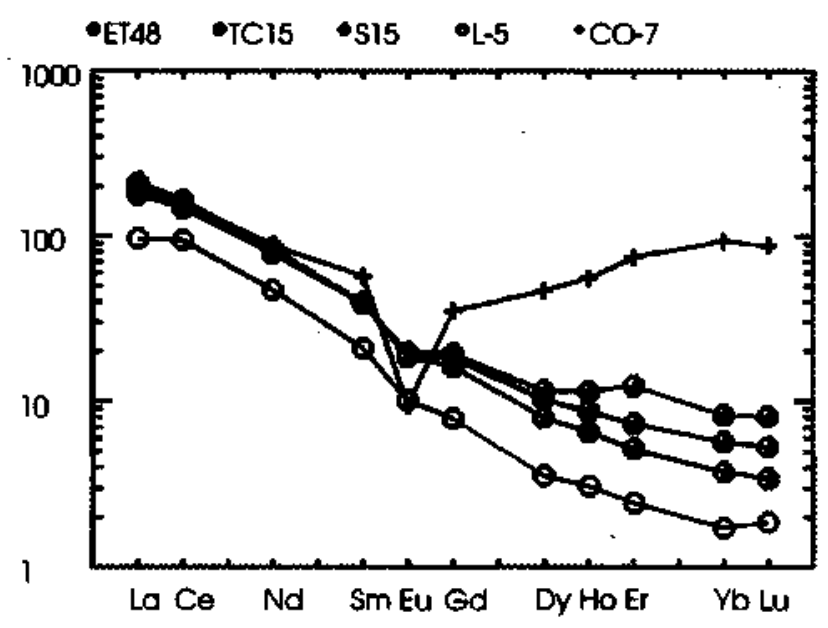

Figure 12 - Diagrama de distribuição de elementos Terras Raras, normalizados pelo condrito de Evensen et al. (1978) multiplicado por 1,27, para granitóides Três Córregos com cerca de $67 \%$ de silica (ET-48, TC-15 e S-15), para granito Lajeado com cerca de $71 \%$ de silica (L-5) e para granito pós-tectônico Correias (CO-7)

Figure 12 - REE distribution patterns, normalised by Evensen et al. (1978) chondrite values multiplied by 1.27 , for Três Córregos granitoids with about $67 \%$ silica (ET-48, TC-15 and S-15), for Lajeado granite with about $71 \%$ silica (L-5), and for post-tectonic Correias granite (CO-7)

De acordo com os campos de distribuição das rochas graníticas dos tipos I, S e A nesse diagrama (Bowden et al. 1984), as rochas granitóides do Complexo Três Córregos situam-se exclusivamente no campo do tipo I, enquanto que os granites da Suíte Pós-Tectônica predominam no campo do tipo A (granites anorogênicos representados por pequenas intrusões de caráter pós-tectônico) havendo, neste último caso, recobrimento com o campo do tipo S.

Os granitóides orientados, anteriormente admitidos por diversos autores como ortognaisses e pertencentes ao embasamento, são petrográfíca e geoquimicamente comparáveis às rochas do Complexo Granítico Três Córregos, onde são incluídos.

Em termos de elementos maiores, o conjunto de granitóides e enclaves do Complexo Granítico Três Córregos constitui, aparentemente, uma seqüência cogenética, que pode ser considerada como básica-intermediária-ácida, cálcio-alcalina de médio a alto-K, de granitóides tipo I, gerados em ambiente compressivo. A exceção parece ser o $\mathrm{MgO}$, que sugere um enriquecimento relativo muito pequeno dos enclaves comparavelmente à tendência dos granitóides. Os padrões de distribuição de elementos incompatíveis, incluindo REE, são em geral semelhantes para as rochas do complexo, excluindo-se os granitos pós-tectônicos, e apresentam típicos componentes de zona de subducção.

Este comportamento geoquímico é comparável ao de diversas suítes de arcos magmáticos, como as rochas da zona vulcânica central dos Andes e do batólito da costa do Peru (e.g., Pearce 1983, Wilson 1989) e de andesitos cálcioalcalinos de arcos magmáticos modernos (Brown 1982). Essas características parecem ser típicas de arcos vulcânicos maduros ou, mais provavelmente, de margem continental ativa. Adicionalmente, podem também ser encontradas em granitos caledonianos, de soerguimento pós-colisional ou alguns granitóides tardi-orogênicos.

Para os granitos da Suíte Pós-Tectônica, os dados geoquímicos indicam tratarem-se de granitos fortemente diferenciados, formados por fusão crustal (tipo A), com campos coincidentes com o dos granitos intraplaca.

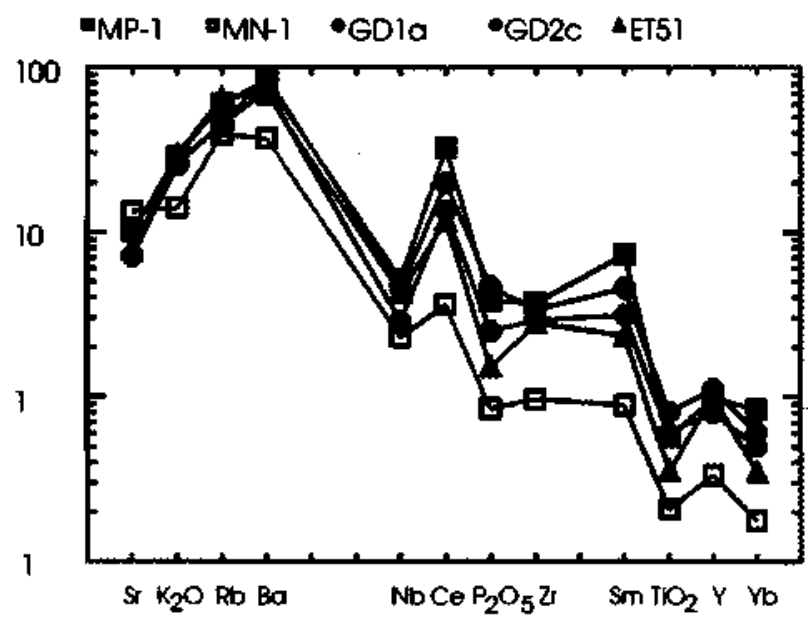

Figura 13 - Diagrama expandido de distribuição de elementos incompativeis, normalizado por N-MORB (Pearce 1983), para enclaves no granitóide Três Córregos (ET-51), nos granitóides orientados (GD-la e GD-2c) e no augen gnaisse (MP-1) e para augen gnaisse (MN-1) Figure 13 - N-MORB normalised (Pearce 1983) incompatible element distribution patterns for enclaves in Três Córregos granitoid (ET-51), foliated granitoids (GD-la and GD-2c), and augen gneiss (MP-1), and for augen gneiss (MN-1)

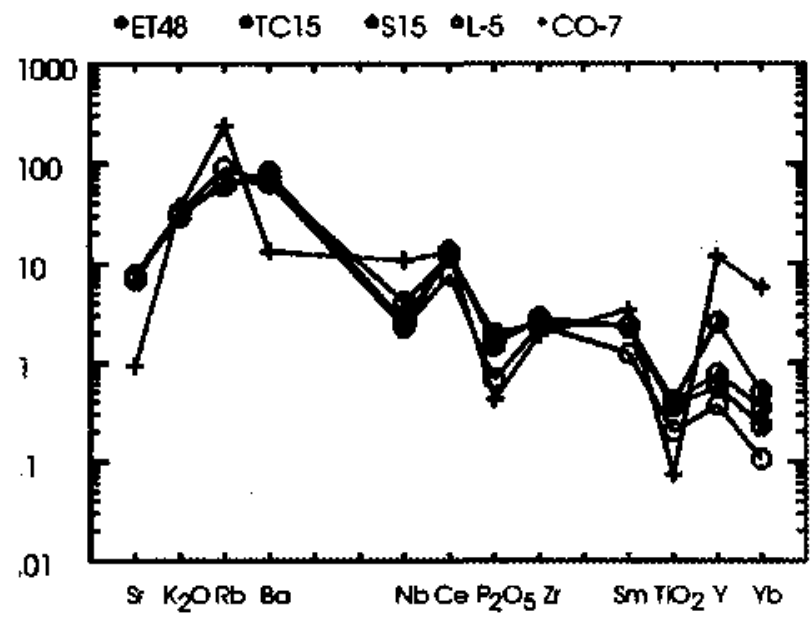

Figura 14 - Diagrama expandido de distribuição de elementos incompativeis, normalizado por N-MORB (Pearce 1983), para granitóides Três Córregos com cerca de 67\% de sítica (ET-48, TC-15 e S-15), para granito Lajeado com cerca de $71 \%$ de silica (L-5) e para granito pós-tectônico Correias (CO-7).

Figura 14 - N-MORB normalised (Pearce 1983) incompatible element distribution patterns for Três Córregos granitoids with about $67 \%$ silica (ET-48, TC-15 and S-15), for Lajeado granite with about $71 \%$ silica (L-5), and for post-tectonic Correias granite (CO-7).

No complexo estudado, a relação entre os enclaves máfícos potássicos e as rochas mais diferenciadas é ainda controversa. A tendência geral de distribuição de elementos maiores e traços sugere processos de cogeneticidade, ou ao menos contemporaneidade, como fracionamento de magmas básicos potássicos para gerar as rochas intermediárias e ácidas, possivelmente com assimilação crustal associada ou mistura de magmas máficos e félsicos. 
A leve diferença na distribuição de $\mathrm{MgO}$ entre os enclaves e granitóides, se significativa, dificultaria modelos como os de cristalização fracionada ou mistura de magmas. As razões isotópicas iniciais $\mathrm{Sr}^{87} / \mathrm{Sr}^{86}(\mathrm{R} ;)$ para os granitóides Três Córregos e seus enclaves (Gimenez Filho 1993) são relativamente elevadas, com valores da ordem de 0,711 a 0,716 , indicando participação crustal, ao menos como contaminante. As RJ dos enclaves e granitóides seriam um pouco diferentes se eles forem considerados como contemporâneos, o que também dificultaria a adoção de modelos de cogeneticidade estrita. As RJ dos enclaves, inclusive, parecem ser um pouco mais elevadas que as de alguns dos granitóides o que está de acordo com seus teores algo mais elevados de elementos incompatíveis. Os enclaves máficos, constituídos predominantemente de dioritos potássicos, parecem ser derivados por fusão parcial de manto enriquecido em elementos incompatíveis e com SZC, provavelmente com alguma assimilação crustal, tendo em vista as RJ elevadas. Os granitóides Três Córregos parecem estar relacionados aos dioritos potássicos por algum processo de diferenciação, ainda mal definido, enquanto os granitos pós-tectônicos seriam produzidos predominantemente por fusão crustal em ambiente intraplaca.

O Complexo Granítico Três Córregos, com sua seqüência cálcio-alcalina de alto-K e enclaves máficos que correspondem a dioritos potássicos, constitui um bom exemplo do plutonismo granitóide, além de seqüências mangeríticas associadas, que ocorre na Microplaca Apiaí-Guaxupé (e.g., Campos Neto \& Figueiredo 1995), com idades ao redor de $650 \mathrm{Ma}$, como recentemente sintetizado por Figueiredo \& Campos Neto (1994).

Agradecimentos Este trabalho foi realizado com apoio financeiro da FAPESP (Processo 88/3806-2).

\section{REFERÊNCIAS BIBLIOGRÁFICAS}

BATCHELOR, R.A. \& BOWDEN, P. 1985. Petrogenetic interpretation of granitoid rock series using multicationic parameters. Chemical Geology, 48:43-55.

BISTRICHI, C.A.; ALMEIDA, M.A. de \& STEIN, D.P. 1985. Geologia das folhas Barra do Chapéu (SG.22-X-B-I-4) e Araçaiba (SG.22-XF-II-3), estados de São Paulo e Paraná. São Paulo, Contrato IPT/ Pró-Minério, vol. 1, 104 p. (IPT. Relatório 22 150) (inédito)

BOWDEN, P.; BATCHELOR, R.A.; CHAPPELL, B.W.; DIDIER, J. \& LAMEYRE, J. 1984. Petrological, geochemical and source criteria for the classification of granitic rocks: a discussion. Physics of the Earth and Planetary Interiors, 35:1-11.

BROWN, G.C. 1982. Calc-Alkaline Intrusive Rocks: their diversity, evolution and relation to volcanic arcs. In: THORPE, R.S. ed. Andesites. New York, Wiley, p. 437-461.

CAMPANHA, G.A. da C. 1991. Tectônica Proterozóica no Alto e Médio Vale do Ribeira, Estados de São Paulo e Paraná. São Paulo. 296 p. (Tese de Doutoramento, IG-USP).

CAMPANHA, G.A. da C.; BISTRICHI, C.A. \& ALMEIDA, M.A. de. 1987. Considerações sobre a organização litoestratigráfica e evolucão tectônica da faixa de dobramentos Apiaí. In: SIMPOSIO SULBRASILEIRO DE GEOLOGIA, 3, Curitiba, 1987. Atas... Curitiba, SBG. v. 2, p. 725-742.

CAMPANHA, G.A.da C.; MACHADO JR., D.de L.; NAGATA, N.; DANTAS, A.S.L.; ENS, H.H.; GIMENEZ FILHO, A.; BISTRICHI, C.A.; FERREIRA, F.J.F.; MONMA, R.; ETCHEBEHERE, M.L.de C.; RONDINELLI, D.; STEIN, D.P.; MAEYAMA, O.; DEHIRA, L.K. \& BORDIGNON, J.L. 1988. Avaliação preliminar da geologia das folhas (em 1:50 000) Taquaral, Mina do Espírito Santo, Ribeirão Itacolomi, Serra doAboboral, Jacupiranga (Eldorado Paulista), Rio Guaraú (Barra do Azeite), Rio Turvo (Serra do Aleixo) • Vale do Ribeira, SP. São Paulo, Convênio IPT/SICCT-Pró-Minério. v. 1-4 (IPT. Relatório, 26863 ) (inédito)

CAMPOS NETO, M.C. \& FIGUEIREDO, M.C.H. 1995. The Rio Doce Orogeny, Southeastern Brazil. Journal of South American Earth Sciences, 8:143-162.

CHIODI FILHO, C.; TAKAHASHI, A. T.; SILVA, C. R. da \& FERREIRA, J.C.G. 1983. Projeto Capão Bonito; relatório final. São Paulo, Contrato CPRM/Pró-Minério (inédito).

CHIODI FILHO, C ; SANTOS, J.F * SOARES, PC \& MORETZJOHN, J.S. 1989. Estudo de ETR para caracterização e avaliação metalogenética de granitóides no escudo paranaense. In: CONGRESSO BRASILEIRO DE GEOQUÍMICA, 2, Rio de Janeiro, 1989. Anais.. Rio de Janeiro, SBGq. v. 2, p. 487-498.

DEBON, F. \& LÊ FORT, P. 1983. A chemical-mineralogical classification of common plutonic rocks and associations. Transactions of the Royal Society of Edinburgh: Earth Sciences, 73 (for 1982):135-149.

DE LA ROCHE, H.; LETERRIER, J.; GRAND CLAUDE, P. \& MARCHAL, M. 1980. A classification of volcanic and plutonic rocks using R1-R2 diagrams and major element analyses - its relationships with current nomenclature. Chemical Geology, 29:183-210.

DUTRA, C.V. 1984. Método para determinação de traços e sub-traços de Terras Raras em rochas por espectrometria de plasma (ICP) - aplicação em petrogênese. In: CONGRESSO BRASILEIRO DE GEOLOGIA, 33, Rio de Janeiro, 1984. Anais... Rio de Janeiro, SBG. v.10, p. $4792-4805$

EL BOUSEILY, A.M. \& EL SOKKARY, A.A. 1975. The relation between $\mathrm{Rb}, \mathrm{Ba}$ and $\mathrm{Sr}$ in granitic rocks. Chemical Geology, 16:207-219.

EVENSEN, N.M.; HAMILTON, P.J. \& O'NIONS, R.K. 1978. Rare-Earth abundances in chondritic meteorites. Geochimica et Cosmochimica Acta, 42:1199-1212.
FIGUEIREDO, M.C.H. \& CAMPOS NETO, M.C. 1994. O arco magmático cálcio-alcalino de alto-K da Microplaca Apiaí-Guaxupé. In: CONGRESSO BRASILEIRO DE GEOLOGIA, 38, Camboriú, 1994. Boletim de Resumos Expandidos... Camboriú, SBG. v. 1, p. 620-621.

FUCK, R.A. 1966. Nota Explicativa da Folha Geológica de Quero-Quero. Boletim da Universidade Federal do Paraná, 19, 21 p.

FUCK, R.A.; MARINI, O.J. \& TREIN, E. 1967. Contribuição ao estudo das rochas graníticas do Estado do Paraná. Boletim Paranaense de Geociências, 23-25:183-221.

GIMENEZ FILHO, A. 1993. Evolução do Complexo Granítico Três Córregos a Noroeste de Apiai $\bullet S P$. São Paulo, 118 p. (Dissertação de Mestrado, IG-USP).

GIMENEZ FILHO, A.; FIGUEIREDO, M.C.H.; TEIXEIRA, W. \& TREVIZOLI JR., L.E. 1992. Litogeoquímica do Complexo Granítico Três Córregos, SP. In: CONGRESSO BRASILEIRO DE GEOLOGIA, 37, São Paulo, 1992. Boletim de Resumos Expandidos ... São Paulo. SBG. v. 1, p. 365-367.

GOMES, C.B ; BERENHOLC, M. HYPÓLITO, R \& ARRUDA, J. R. de. 1975a. Geoquímica de maciços graníticos da região do Ribeira. Parte 1. Elementos principais. Anais da Academia Brasileira de Ciências, 47(1):113-130

GOMES, C.B.; ARRUDA, J. R. de; BERENHOLC, M. \& HYPÓLITO, R. 1975b. Geoquímica dos macicos graníticos da região do Ribeira. Parte 2. Elementos traços. Anais da Academia Brasileira de Ciências, 47(3-4):459-476.

GORAIEB, C.L.; MELLO, I.S.C. \& SILVA, R.B. 1987. Geologia e prospecção da área do Bairro dos Correias, Município de Ribeirão Branco (SP). In: SIMPOSIO REGIONAL DE GEOLOGIA, 6, Rio Claro, 1987. Atas... Rio Claro, SBG/NSP. v. 2, p.491-502.

GORAIEB, C.L.; OLIVEIRA, M.C.B.; MELLO, I.S.C. \& SILVA, R.B 1988. As mineralizacões estano-tungsteníferas do Granito Correias (SP). In: CONGRESSO LATINO-AMERICANO DE GEOLOGIA, 7, Belém, 1988. Anais... Belém, SBG. v.1, p.154-172.

HASUI, Y.; CREMONINI, O.A. \& BORN, H. 1984. O "Granito Três Córregos" revisado e o Maciço Catas Altas. In: CONGRESSO BRASILEIRO DE GEOLOGIA, 33, Rio de Janeiro, 1984. Anais... Rio de Janeiro, SBG. v.7, p. 3023-3031.

IRVINE. T.N. \& B AR AG AR, W.R.B. 1971. A guide to the chemical classification of the common volcanic rocks. Canadian Journal of Earth Sciences, 8:523-548.

KAUL, P.F.T. 1984. Significado dos granitos anorogênicos da Suíte Intrusiva Serra do Mar na evolução da crosta do Sul-Sudeste do Brasil, no âmbito das folhas SG.22 - Curitiba e SG.23 - Iguape. In: CONGRESSO BRASILEIRO DE GEOLOGIA, 33, Rio de Janeiro, 1984. Anais... Rio de Janeiro, SBG. v. 6, p. 2815-2825.

LAMEYRE, J. \& BOWDEN, P. 1982. Classification of plutonic rocks: discrimination of various granitic series by their modal composition. Journal of Volcanology and Geothermal Research, 14:169-186.

LE MAITRE, R.W. (ed.) 1989. A classification of igneous rocks and glossary of terms. Oxford, Blackwell, $193 \mathrm{p}$.

MANIAR, P.O. \& PICCOLI, P.M. 1989. Tectonic discrimination of granitoids. Geological Society of America Bulletin, 101:635-643.

MARINI, O.J.; TREIN, E. \& FUCK, R.A. 1967. O Grupo Açungui no Estado do Paraná. Boletim Paranaense de Geociências, 23-25:43-104.

MELCHER, G.C.; GOMES, C.B.; CORDANI, U.G.; BETTENCOURT, J.S.; DAMASCENO, E.C.; GIRARDI, V.A.V. \& MELFI, A.J. 1973. Geologia e petrografia das rochas metamórficas e graníticas associadas ao Vale do Rio Ribeira de Iguape, SP e PR. Revista Brasileira de Geociências, 3(2):97-123. 
MURATORI, A. 1966. Nota Explicativa da Folha Geológica de Campo Largo. Boletim da Universidade Federal do Paraná, 21. $31 \mathrm{p}$

PAIVA, IP ; ALGARTE, J. P - COLANERI, S ; LOPES JR, L; RODRIGUES, J. C. \& SÁ, L. C. M. de 1977. Projeto Leste do Paraná; Folha Apiaí (SG.22-X-B-IV). Brasil; relatório final. São Paulo, DNPM. BADEP.IGUFP.CPRM.

PEACOCK, M.A. 1931. Classification of igneous rock series. Journal of Geology, 39:54-67.

PEARCE, J.A. 1983. Role of the sub-continental lithosphere in magma genesis at active continental margins. In: HAWKESWORTH, C.J. \& NORRY, MJ. eds. Continental basalts and mantle xenoliths. Nantwich, Shiva, p. 230-249.

PEARCE, J.A · HARRIS, N.B.W \& TINDLE, A.G. 1984. Trace element discrimination diagrams for the tectonic interpretation of granitic rocks. Journal of Petrology, 25 (4):956-983.

PUPIN, J.P. 1980. Zircon and granite petrology. Contributions to Mineralogy and Petrology, 73:207-220.

REIS NETO, J.M. dos 1984. Faixa Itaiacoca: registro de uma colisão entre dois blocos continentais no Neoproterozóico. São Paulo. $253 \mathrm{p}$. (Tese de Doutoramento, IG-USP).

SOARES, P.C. 1987. Seqüências tecto-sedimentares e tectônica deformadora no centro-oeste do escudo Paranaense. In: SIMPÓSIO SULBRASILEIO DE GEOLOGIA, 3, Curitiba, 1987. Atas... Curitiba, SBG. v. 2, p.743-771.

SOARES, P.C. 1988. Tectônica colisional em tomo do Bloco Paraná, Brasil. In: CONGRESSO LATINO-AMERICANO de GEOLOGIA, 7 Belém, 1988. Anais... Belém, SBG. v. 1, p. 63-79.
STRECKEISEN, A.L. 1976. To each plutonic rock its proper name. EarthScience Reviews, 12:1-33.

TAKAHASHI A.T; FERREIRA, J.C.G. \& THEODOROVICZ, A. 1984 Projeto Guapiara-, relatório final. São Paulo, Contrato CPRM/PróMinério. (inédito)

THEODOROVICZ, A., CÂMARA, M.M., TAKAHASHI, A.T., MORAES, S.M., GODOY H.K 1988 Geologia do Pré-Cambriano das folhas Engenheiro Maia e Ribeirão Branco, São Paulo. In: CONGRESSO BRASILEIRO DE GEOLOGIA, 35, Belém, 1988. Anais... Belém BRASILEIRO DE GEOLO
SBG. v. 6, p. 2713-2726.

WERNICK. E.; RIGO JÚNIOR, L.; GALEMBECK, T.M.B. \& WEBERDIEFENBACH, K. 1990a. Os complexos granitóides Cunhaporanga e Três Córregos (PR): zoneamento magmático e implicações geotectônicas. Geociências, 9:67-85.

WERNICK. E.; GALEMBECK, T.M.B.; RIGO JÚNIOR, L.; ARTUR, A.C. \& WEBER-DIEFENBACH. K. 1990b. Razão Sr-Ba-Rb e tipologia de zircão em granitóides dos estados de São Paulo, Paraná e Minas Gerais. Geociências, 9:87-160.

WILSON, M. 1989. Igneous petrogenesis: a global tectonic approach. London, Unwin Hyman. 466 p.

MANUSCRITO A840 Recebido em 6 de fevereiro de 1995 Revisão do autor em 20 de marco de 1996 Revisão aceita em I de abril de 1996 